\title{
Zinc oxide nanoparticles induce toxic responses in human neuroblastoma SHSY5Y cells in a size- dependent manner
}

This article was published in the following Dove Press journal:

International Journal of Nanomedicine

I November 2017

Number of times this article has been viewed

Jia Liu'

Yiyuan Kang'

Suhan Yin'

Bin Song ${ }^{2}$

Limin $\mathrm{Wei}^{3}$

Liangjiao $\mathrm{Chen}^{4}$

Longquan Shao'

'Department of Stomatology, Nanfang Hospital, Southern Medical University, Guangzhou, ${ }^{2}$ Department of Stomatology, Guizhou Provincial People's Hospital, Guiyang, ${ }^{3}$ Department of Pediatric Dentistry, School and Hospital of Stomatology, Wenzhou Medical University, Wenzhou, ${ }^{4}$ Key Laboratory of Oral Medicine, Guangzhou Institute of Oral Disease, Stomatology Hospital of Guangzhou Medical University, Guangzhou, China
Correspondence: Longquan Shao Department of Stomatology, Nanfang Hospital, Southern Medical University, 1838 Guangzhou North Avenue, Baiyun Qu, Guangzhou, Guangdong 510515 , China

Tel +86 I59 89283921

Email shaolongquan@smu.edu.cn
Abstract: Due to the widespread applications of zinc oxide nanoparticles ( $\mathrm{ZnO} \mathrm{NPs}$ ), the potential exposure of workers, consumers, and scientists to these particles has increased. This potential for exposure has attracted extensive attention in the science community. Many studies have examined the toxicological profile of ZnO NPs in the immune system, digestive system, however, information regarding the toxicity of ZnO NPs in the nervous system is scarce. In this study, we detected the cytotoxicity of two types of $\mathrm{ZnO}$ NPs of various sizes - $\mathrm{ZnO}^{\mathrm{a}} \mathrm{NPs}$ and $\mathrm{ZnO}^{\mathrm{b}} \mathrm{NPs}$ - and we characterized the shedding ability of zinc ions within culture medium and the cytoplasm. We found that reactive oxygen species played a crucial role in $\mathrm{ZnO}$ NP-induced cytotoxicity, likely because zinc ions were leached from ZnO NPs. Apoptosis and cytoskeleton changes were also toxic responses induced by the $\mathrm{ZnO}$ NPs, and $\mathrm{ZnO}^{\mathrm{b}} \mathrm{NPs}$ induced more significant toxic responses than $\mathrm{ZnO}^{\mathrm{a}} \mathrm{NPs}$ in SHSY5Y cells. In conclusion, ZnO NPs induced toxic responses in SHSY5Y cells in a size-dependent manner, which can probably be attributed to their ion-shedding ability.

Keywords: zinc oxide, nanoparticles, SHSY5Y cells, reactive oxygen species, apoptosis, cell cytoskeleton

\section{Introduction}

The use of engineered nanoparticles (NPs) has increased, because their application in various fields, such as electronics, biomedicine, pharmaceuticals, cosmetics, energy applications, and materials, has expanded rapidly during the past few decades. ${ }^{1}$ Meanwhile, their toxic side effects are increasing daily. Recently, various investigators have striven to elucidate the deleterious effects of these nanomaterials. ${ }^{2,3}$ Some of these NPs, such as silver, titanium dioxide $\left(\mathrm{TiO}_{2}\right)$ and zinc oxide NPs ( $\mathrm{ZnO}$ NPs), which are widely detected in living environments, drinking water, and various consumer products, have been reported to induce inflammation, oxidative stress, and cytotoxicity. ${ }^{2,4} \mathrm{ZnO}$ NPs have been widely used in drug delivery, the pharmaceutical industry, biomedical engineering, sunscreens, food additives, and cosmetics. ${ }^{5}$ Due to the large increase in the prevalence of nanomaterials, the potential of increased exposure exists for consumers, industry workers, and hence more research should be performed to mitigate their toxic side effects.

$\mathrm{ZnO}$ NPs show higher toxic effects than other metallic oxide NPs, such as $\mathrm{TiO}_{2}{ }^{6-8}$ likely because of their ion-shedding ability. ZnO NPs exhibit low solubility under neutral conditions, but are readily soluble under acidic conditions, such as in lysosomes. ${ }^{9,10}$ This behavior is similar to that of other soluble metallic NPs, such as silver. ${ }^{11,12}$ However, when 
compared with $\mathrm{ZnO}$ NPs, silver exhibits lower solubility in acidic conditions and higher solubility in neutral conditions. ${ }^{9,11}$ The principal neurotoxic mechanism of $\mathrm{ZnO}$ NPs is the mass production of reactive oxygen species (ROS) via the disturbance of metal-ion homeostasis due to an intracellular increase in dissolved free zinc ions. ${ }^{13,14}$ Elevated levels of zinc ions are considered the major contributor to $\mathrm{ZnO}$ NP-induced cytotoxicity, causing oxidative stress ${ }^{3}$ and inflammation. ${ }^{15}$

Various studies have shown that $\mathrm{ZnO}$ NPs with various shapes, such as rods and spheres, probably cause neurotoxicity due to their ability to access the brain. ${ }^{16-18}$ Moreover, the olfactory brain route has also been reported as a potential route for $\mathrm{ZnO}$ NPs transfer into the brain. ${ }^{19}$ However, information regarding the neurotoxic effects of $\mathrm{ZnO}$ NPs is scarce. Therefore, understanding the effects of nanomaterial exposure, including neurotoxicity, is important for ensuring the safety of nanomaterials, particularly when the particles are used in biomedical applications. Cytotoxicity severity has been shown to depend on the physicochemical properties of the NPs, such as chemical composition, size, shape, aggregation, surface chemistry, and surface energy. ${ }^{20-23}$ The physicochemical characteristics of NPs, such as being sufficiently small to penetrate the blood-brain barrier, and their large surface area can promote their neurotoxicity. ${ }^{24}$

Therefore, we aimed to investigate the toxic effects of ZnO NPs in neuronal SHSY5Y cells by assessing their cytotoxic effects, oxidative stress, apoptotic damage, and morphological changes under in vitro conditions. Meanwhile, we discuss the toxic effects of two types of $\mathrm{ZnO}$ NPs with different physicochemical properties and investigate the role of zinc ions in $\mathrm{ZnO}$ NP-induced toxic effects.

\section{Materials and methods Chemicals}

$\mathrm{ZnO}^{\mathrm{a}} \mathrm{NPs}$ were purchased from Sigma-Aldrich (677450; St Louis, MO, USA), as were $\mathrm{ZnO}^{\mathrm{b}} \mathrm{NPs}$ (544906) and zinc chloride $\left(\mathrm{ZnCl}_{2} ; \mathrm{Z} 0152\right)$. FBS, DMEM, FluoZin-3 AM, Lyso Tracker Red DND-99, Hoechst 33342, and Alexa Fluor 594 phalloidin were purchased from Thermo Fisher Scientific (Waltham, MA, USA). The monoclonal anti- $\alpha$-tubulin antibody was purchased from Sigma-Aldrich. NPs were dispersed by probe sonication for 120 minutes in PBS to yield a stock solution of $1 \mathrm{mg} / \mathrm{mL}$. All other reagents were of the highest purity, commercially available, and used as received.

\section{Concentration of dissolved zinc in cell- culture medium}

ZnONP suspensions $(0,5,10,25,50,75$, and $100 \mu \mathrm{g} / \mathrm{mL})$ were prepared using complete culture medium and incubated for
24 hours at $37^{\circ} \mathrm{C}$. The suspensions were then centrifuged at 20,000 rpm for 30 minutes. Supernatants were then transferred into $1.5 \mathrm{~mL}$ centrifuge tubes for analysis. Zinc content was detected using an inductively coupled plasma mass spectrometry (X-Series 2; Thermo Fisher Scientific).

\section{SHSY5Y cell cultures and differentiation}

The human neuroblastoma SHSY5Y cell line was obtained from the cell bank of the Shanghai Infrastructure for Public Research and Development of the Chinese Academy of Medical Sciences. DMEM supplemented with $10 \%$ FBS and $1 \%$ penicillin-streptomycin (Thermo Fisher Scientific) was used for SHSY5Y cell culture, and the cells were incubated at $37^{\circ} \mathrm{C}$ with $5 \% \mathrm{CO}_{2}$. The culture medium was replaced every other day, and cells were passaged when confluence reached $80 \%-90 \%$. To obtain cells with neuronal phenotypes, we attempted to induce differentiation in SHSY5Y cells using trans-retinoic acid, and we observed morphology changes at $0,3,6,9,12$, and 15 days.

To investigate the biological effects of the $\mathrm{ZnO}$ NPs, SHSY5Y cells were incubated in a complete culture medium for 24 hours before the addition of the $\mathrm{ZnO}$ NPs at various concentrations. The $\mathrm{ZnO}$ NPs were diluted to $100 \mu \mathrm{g} / \mathrm{mL}$ from a stock solution of $1 \mathrm{mg} / \mathrm{mL}$, dispersed for 30 minutes with a sonicator to prevent aggregation, and then diluted to the specified concentrations for treating the cells. We list the relative relationships between the different concentrations of the $\mathrm{ZnO}$ NPs and $\mathrm{ZnCl}_{2}$ in Table 1 .

\section{Cell-proliferation assays after $\mathrm{ZnO}$ NP and $\mathrm{ZnCl}_{2}$ treatments}

Cellular viability was determined using the CCK-8 assay (Dojindo Molecular Technologies, Kumamoto, Japan). Cells were seeded in each well in 96-well plates with 5,000 cells/ well. Then, $100 \mu \mathrm{L}$ of the complete culture medium was added per well and cells incubated for 24 hours at $37^{\circ} \mathrm{C}$. The $\mathrm{ZnO}$ NPs were then added to the 96-well plates at concentrations of $5,10,20,40,60,80$, and $100 \mu \mathrm{g} / \mathrm{mL}$, and $\mathrm{ZnCl}_{2}$ was added at concentrations of $61.4,122.9,245.7,491.5,737.2,982.9$, and $1,228.7 \mu \mathrm{M}$. The plates were incubated for $2,6,12$, or 24 hours

Table I Relative relationship between $\mathrm{ZnO} N P s$ and $\mathrm{ZnCl}_{2}$ at different concentrations

\begin{tabular}{lllllllll}
\hline Type of particle & \multicolumn{8}{l}{ Concentration } \\
\hline Zinc element $(\mu \mathrm{M})$ & 61.4 & 122.9 & 245.7 & 491.5 & 737.2 & 982.9 & $1,228.7$ \\
Zinc element $(\mu \mathrm{g} / \mathrm{mL})$ & 4.02 & 8 & 16.1 & 32.1 & 48.2 & 64.3 & 80.33 \\
$\mathrm{ZnO}(\mu \mathrm{g} / \mathrm{mL})$ & 5 & 10 & 20 & 40 & 60 & 80 & 100 \\
$\mathrm{ZnCl}_{2}(\mu \mathrm{g} / \mathrm{mL})$ & 8.37 & 16.75 & 33.5 & 67 & 100.5 & 134 & 167.46 \\
\hline
\end{tabular}

Abbreviation: NPs, nanoparticles. 
at $37^{\circ} \mathrm{C}$. The control group was untreated. Finally, detection reagents were added to each well, and the 96 -well plates were then incubated for an additional 2 hours at $37^{\circ} \mathrm{C}$. To prevent the NPs from interfering in this analytical assay, an empty 96-well plate was prepared and the solution from each well quantitatively transferred to the empty plate. Subsequently, absorbance was measured using a microplate reader at a wavelength of $450 \mathrm{~nm}$. Six replicates were performed for each treatment. Moreover, $\mathrm{N}$-acetyl-L-cysteine (NAC), an ROS scavenger, was used to detect the role of ROS in the $\mathrm{ZnO}$ NP-induced toxic response. SHSY5Y cells were incubated with the $\mathrm{ZnO}$ NPs or $\mathrm{ZnCl}_{2}$ for 24 hours, accompanied by NAC (10 mM), and then cells were evaluated as previously described.

\section{Confocal study of zinc ion-release process after $\mathrm{ZnO} \mathrm{NP}$ treatment}

The human neuroblastoma SHSY5Y cell line was treated with $50 \mu \mathrm{g} / \mathrm{mL}$ of the ZnO NPs for 1, 3, or 5 hours. After treatment, cells were loaded with $3 \mu \mathrm{M}$ FluoZin- 3 at $37^{\circ} \mathrm{C}$ for 60 minutes. The cells were then washed twice with PBS and incubated with the culture medium at $37^{\circ} \mathrm{C}$ for 30 minutes to enable complete penetration of the fluorescence probe. Then, the culture medium was removed, and cells were loaded with $70 \mathrm{nM}$ LysoTracker red DND-99 at $37^{\circ} \mathrm{C}$ for 1 hour. Finally, cell nuclei were loaded with Hoechst 33342 at $37^{\circ} \mathrm{C}$ for 20 minutes. Before fluorescence was observed, cells were washed twice with PBS and sealed with an antifade mounting medium (Beyotime, Haimen, China). All fluorescence measurements were obtained under confocal microscopy (FV10i; Thermo Fisher Scientific).

\section{ROS-level detection in SHSY5Y cells after $\mathrm{ZnO}$ NP exposure}

The formation of intracellular ROS was determined using an ROS-assay kit (Beyotime). Briefly, after being washed with PBS, $2 \times 10^{5}$ cells were seeded per well in a six-well plate at a volume of $2 \mathrm{~mL}$. Then, cells were treated with two types of $\mathrm{ZnO}$ NPs at a concentration of $25 \mu \mathrm{g} / \mathrm{mL}$ for 1,6 , 12 , and 24 hours or at a concentration of $50 \mu \mathrm{g} / \mathrm{mL}$ for 1,3 , and 5 hours. $\mathrm{ZnCl}_{2}$ was used to analyze the toxic effects of the zinc ions in $\mathrm{ZnO}$ NP supernatants. After treatment with $\mathrm{ZnO} N \mathrm{Ns}$ and $\mathrm{ZnCl}_{2}$, cells were collected and incubated with $10 \mu \mathrm{M}$ dichlorodihydrofluorescein diacetate for 30 minutes at $37^{\circ} \mathrm{C}$ and $5 \% \mathrm{CO}_{2}$. Then, fluorescence intensity was analyzed using a FACSAria III (BD, Franklin Lakes, NJ, USA).

\section{Cell-apoptosis detection via annexin $\mathrm{V}-$ FITC/PI detection assay}

Annexin V-fluorescein isothiocyanate (FITC) and propidium iodide (PI) assays (Thermo Fisher Scientific) were conducted to detect cell apoptosis. The annexin V-FITC assay consists of an FITC-conjugated annexin V antibody that has a high affinity for membrane phosphatidylserine. In normal viable cells, the phosphatidylserine is located on the inner side of the cell membrane. Then, the phosphatidylserine flips and becomes exposed on the outer side of the plasma membrane upon activation of the cell-apoptosis pathway. This behavior can be used to detect the early apoptosis of cells. In addition, cells were incubated with PI, which cannot penetrate the cell membranes of viable cells or cells in an early apoptotic phase, and then cell nuclei were stained. However, PI can stain nuclei via penetrating the cell membranes of necrotic cells and cells in a late apoptotic phase. Using both dyes in combination with two-wavelength flow cytometry, apoptotic and necrotic cells were identified separately. Following 5 hours of incubation with different concentrations of $\mathrm{ZnO}$ NPs $(0,20,40$, and $60 \mu \mathrm{g} / \mathrm{mL})$, cells were washed and stained with annexin V and PI. SHSY5Y cells were resuspended in $100 \mu \mathrm{L}$ binding buffer and $5 \mu \mathrm{L}$ FITC-conjugated annexin $\mathrm{V}$, and $5 \mu \mathrm{L}$ PI was added sequentially at room temperature in the dark. After 15 minutes of incubation, stained cells were diluted with $400 \mu \mathrm{L}$ binding buffer and analyzed directly using the FACSAria.

\section{RNA extraction and RT-PCR}

Total RNA was extracted using Trizol reagent (Thermo Fisher Scientific), and RNA concentration was detected using ultraviolet spectrophotometry. Then, RNA was reverse-transcribed to cDNA using a reverse-transcription (RT) reagent kit (Takara Bio, Dalian, China). Real-time polymerase chain reaction (PCR) was conducted using SYBR green (Takara Bio). Several genes were detected: $S O D 1, S O D 2, C A T$, $G P X 1, B A X, B C L 2$, and $C Y T C$. Data were analyzed using the $2^{-\triangle \triangle \mathrm{CT}}$ method. The primers used are listed in Table 2.

\section{Confocal study of cytoskeleton changes after $\mathrm{ZnO}$ NP treatment}

The human neuroblastoma SHSY5Y cell line was treated with $50 \mu \mathrm{g} / \mathrm{mL} \mathrm{ZnO} \mathrm{NPs} \mathrm{for} \mathrm{1,} \mathrm{3,} \mathrm{or} 5$ hours. After treatment, cells were treated with $4 \%$ paraformaldehyde for 20 minutes. Cells were then washed twice with PBS and treated with $1 \%$ Triton for 10 minutes. Then, cells were blocked via 5\% $\mathrm{BSA}$ at $37^{\circ} \mathrm{C}$ for 1 hour and subsequently incubated with the monoclonal anti- $\alpha$-tubulin antibody overnight at $4^{\circ} \mathrm{C}$. Cells were washed three times for 10 min each with PBS. Afterward, cells were loaded with FITC-bound secondary antibody at $37^{\circ} \mathrm{C}$ for 1 hour. Additionally, cells were loaded with phalloidin, which can bind actin, at $37^{\circ} \mathrm{C}$ for 1 hour. Finally, cell nuclei were stained with Hoechst 33342 at $37^{\circ} \mathrm{C}$ 
Table 2 Primers used for polymerase chain reaction

\begin{tabular}{|c|c|c|}
\hline Gene & Forward & Reverse \\
\hline SODI & 5'-CAGTGCAGGTCCTCACTTTA-3' & 5'-CCTGTCTTTGTACTTTCTTC-3' \\
\hline SOD2 & 5'-GGACAAACCTCAGCCCTAAC-3' & 5'-TTGAAACCAAGCCAACCC-3' \\
\hline CAT & 5'-AGGGGCCTTTGGCTACTTTG-3' & 5'-ACCCGATTCTCCAGCAACAG-3' \\
\hline GPXI & 5'-AGAACGCCAAGAACGAAGAG-3' & 5'-ACAGGACCAGCACCCATCT-3' \\
\hline$B A X$ & 5'-CCAGCTGCCTTGGACTGTGT-3' & 5'-GGTTTATTACCCCCTCAAGACCAC-3' \\
\hline$B C L 2$ & 5'-GGTGAACTGGGGGAGGATTG-3' & 5'-GACAGCCAGGAGAAATCAAACAG-3' \\
\hline CYTC & 5'-GCCCCTGGATACTCTTACAC-3' & 5'-TCTGCCCTTTCTTCCTTCT-3' \\
\hline
\end{tabular}

for 20 minutes. Before fluorescence observation, cells were washed twice with PBS and sealed with an antifade mounting medium. All fluorescence measurements were obtained under confocal microscopy (FV10i).

\section{Statistical analysis}

Results are represented as means \pm SEM. All data were assessed by analysis of variance. The homogeneity-ofvariance test was performed, and Bonferroni and Dunnett's T3 tests were used when equal variance was assumed and there was no homogeneity, respectively. $P<0.05$ was considered significant.

\section{Results}

\section{Characterization of ZnO NPs}

Prior to biological testing, we characterized $\mathrm{ZnO}$ NP powders via transmission electron microscopy and dynamic light scattering. Transmission electron-microscopy data were used to determine particle shapes and sizes. $\mathrm{ZnO}^{\text {a }} \mathrm{NPs}$ were irregular and rod-shaped with smooth surfaces, average size was $47.1 \pm 5.1 \mathrm{~nm}$, and width $27.9 \pm 1.8 \mathrm{~nm}$. The $\mathrm{ZnO}^{\mathrm{b}} \mathrm{NPs}$ were small and rod-shaped, average size was $18.5 \pm 1.2 \mathrm{~nm}$, and width $6.8 \pm 0.5 \mathrm{~nm}$ (Figure 1A, Table 3). The size of $\mathrm{ZnO}^{\mathrm{a}}$ NPs detected via dynamic light scattering was $90.8 \mathrm{~nm}$, and that of $\mathrm{ZnO}^{\mathrm{b}} \mathrm{NPs} 49.4 \mathrm{~nm}$ (Figure 1B, Table 3). Both $\mathrm{ZnO}$ NP types were detected to be larger in water, evidencing the agglomeration effect of the particles in water. $\zeta$-Potentials of both $\mathrm{ZnO} \mathrm{NP}$ types were determined, and significant differences were not observed $\left(\mathrm{ZnO}^{\mathrm{a}} \mathrm{NPs} 14.8 \pm 11.3 \mathrm{mV}, \mathrm{ZnO}^{\mathrm{b}}\right.$ NPs $15.3 \pm 9.33 \mathrm{mV})$.

\section{Zinc ions released from $\mathrm{ZnO} N P s$ in culture medium}

To explore zinc-ion levels released from the two types of $\mathrm{ZnO}$ NPs in extracellular fluid, we detected zinc concentrations in the culture medium at various concentrations (Figure 1C). We found that zinc-ion levels in the culture medium increased in a concentration-dependent manner. The highest zinc concentration was nearly $6 \mu \mathrm{g} / \mathrm{mL}$ at a concentration of $100 \mu \mathrm{g} / \mathrm{mL}$ for the $\mathrm{ZnO}^{\mathrm{a}} \mathrm{NPs}$; this result was slightly lower than that of the $\mathrm{ZnO}^{\mathrm{b}} \mathrm{NPs}$ (nearly $6.7 \mu \mathrm{g} / \mathrm{mL}$ ). Moreover, zinc concentrations in the culture medium following treatment with the two types of ZnO NPs at concentrations of $25 \mu \mathrm{g} / \mathrm{mL}$ and $50 \mu \mathrm{g} / \mathrm{mL}$ were approximately $2 \mu \mathrm{g} / \mathrm{mL}$ (nearly $30.7 \mu \mathrm{M}$ ) and $4 \mu \mathrm{g} / \mathrm{mL}$ (nearly $61.4 \mu \mathrm{M}$ ), respectively.

\section{Trans-retinoic acid-induced SHSY5Y-cell differentiation}

We used trans-retinoic acid to differentiate SHSY5Y cells and observed cell-morphology changes at $0,3,6,9,12$, and 15 days (Figure 2). We found that SHSY5Y cells were polygonal without any activation. After trans-retinoic acid incubation, cells extended a few pseudopodia, which were elongated in a time-dependent manner. Moreover, a large number of SHSY5Y cells exhibited spindle shapes after trans-retinoic acid treatment for more than 12 days.

\section{Two types of ZnO NP-induced viability changes in SHSY5Y cells}

We detected the viability of SHSY5Y cells after treatment with the two $\mathrm{ZnO} \mathrm{NP}$ types and $\mathrm{ZnCl}_{2}$. We did not observe toxic effects from the ZnO NPs after 2 hours of treatment. Following $\mathrm{ZnO}^{\mathrm{a}} \mathrm{NP}$ treatment (Figure 3A), no significant viability changes were observed in SHSY5Y cells at concentrations $\leq 20 \mu \mathrm{g} / \mathrm{mL}$ for any time point. However, $\mathrm{ZnO}^{\mathrm{a}} \mathrm{NP}$ concentrations $>20 \mu \mathrm{g} / \mathrm{mL}$ showed potent viability decrease in a time-dependent manner. Following $\mathrm{ZnO}^{\mathrm{b}} \mathrm{NP}$ treatment (Figure 3B), the results showed concentration-dependent toxic effects at 6,12 , and 24 hours. Toxic effects were more significant at concentrations $\geq 20 \mu \mathrm{g} / \mathrm{mL}$.

When cells were treated with $\mathrm{ZnO}$ NPs at concentrations below $20 \mu \mathrm{g} / \mathrm{mL}$, slight toxic effects were observed with the $\mathrm{ZnO}^{\mathrm{b}} \mathrm{NPs}$, while no toxic effects were detected with the $\mathrm{ZnO}^{\mathrm{a}}$ NPs. Moreover, compared with $\mathrm{ZnO}^{\mathrm{a}} \mathrm{NPs}$, with $\mathrm{ZnO}^{\mathrm{b}} \mathrm{NPs}$ at concentrations $\geq 20 \mu \mathrm{g} / \mathrm{mL}$, we detected more significant cell-viability decrease. $\mathrm{ZnO}^{\mathrm{b}} \mathrm{NPs}$ decreased cell viability to $<10 \%$ at the highest concentration $(100 \mu \mathrm{g} / \mathrm{mL})$ after 24 hours, while $\mathrm{ZnO}^{\mathrm{b}}$ NPs reduced cell viability to $20 \%$.

Our results showed that $\mathrm{ZnCl}_{2}$ had significantly higher toxic effects than the two $\mathrm{ZnO}$ NP types at the same zinc 


\section{A}

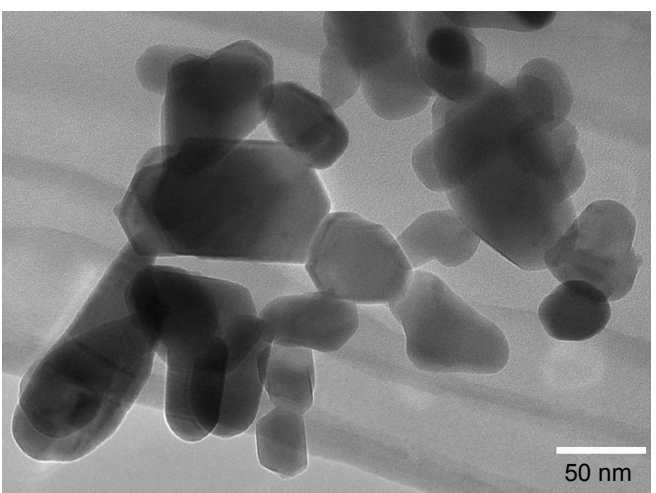

ZnOa NPs

B
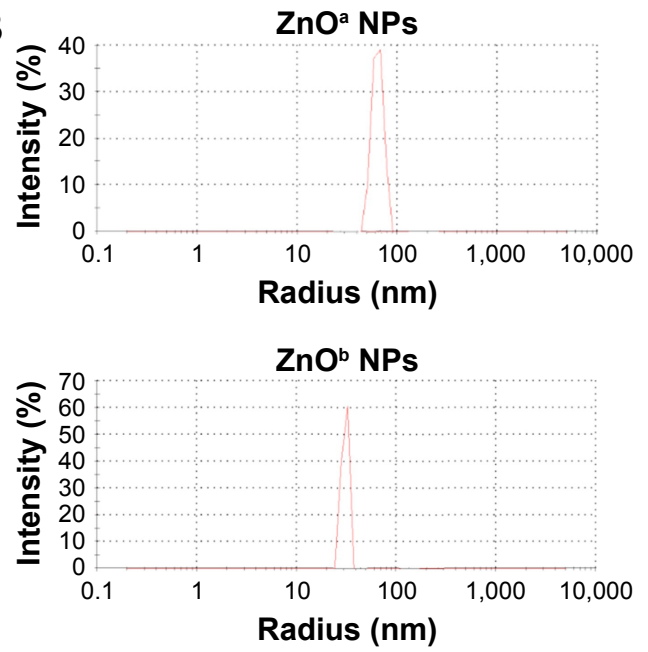

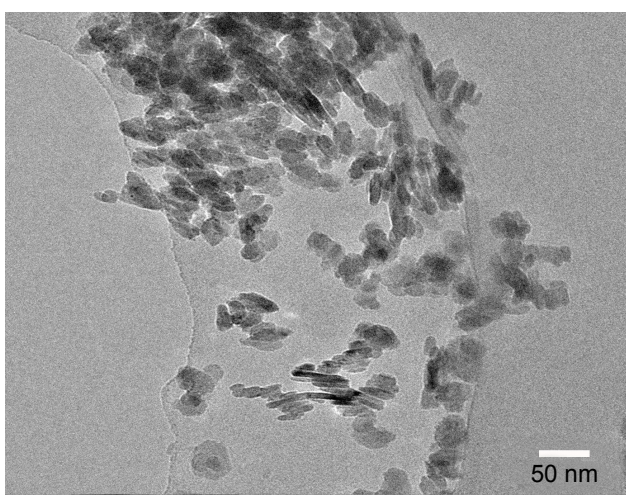

$\mathrm{ZnO}^{\mathrm{b}}$ NPs

C

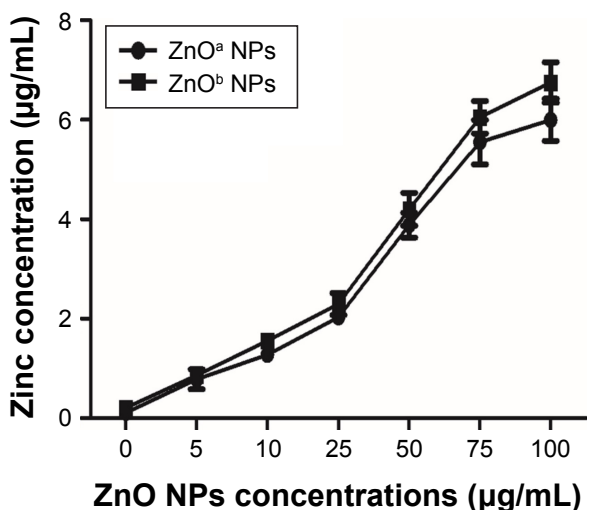

Figure I Characterization of ZnO NPs.

Notes: ZnO NP morphology and size were detected using TEM (A). DLS (B) was used to determine NP distribution in an aqueous solution. (C) Zinc concentrations in supernatants of $\mathrm{ZnO} N P$ suspensions at various concentrations $(0,5,10,25,50,75$, and $100 \mu \mathrm{g} / \mathrm{mL})$. Scale bar $=50 \mathrm{~nm}$.

Abbreviations: DLS, dynamic light scattering; NPs, nanoparticles; TEM, transmission electron microscopy.

molar concentration (Figure 3C). Similar toxic effects in a time- and concentration-dependent manner were observed. Following $\mathrm{ZnCl}_{2}$ treatment, toxic effects were detected at concentrations of $61.4 \mu \mathrm{M}$, and cell viability rapidly decreased to approximately $10 \%$ at a concentration of $122.9 \mu \mathrm{M}$ after 24 hours of treatment. Moreover, a significant decrease in cell viability was observed with $\mathrm{ZnCl}_{2}$ treatment for 2 hours.

\section{Immunocytochemistry of intracellular zinc ions and lysosomes}

We detected the zinc ion-shedding process in cells using immunocytochemistry after exposure to $\mathrm{ZnO}^{\mathrm{a}} \mathrm{NPs}$ (Figure $4 \mathrm{~A}$ )

Table 3 Characterization of ZnO NPs

\begin{tabular}{llllll}
\hline $\begin{array}{l}\text { Type of } \\
\text { particle }\end{array}$ & $\begin{array}{l}\text { Average } \\
\text { size }(\mathbf{n m})\end{array}$ & $\begin{array}{l}\text { Average } \\
\text { width }(\mathbf{n m})\end{array}$ & $\begin{array}{l}\text { DLS } \\
(\mathbf{n m})\end{array}$ & $\begin{array}{l}\zeta \text {-Potential } \\
(\mathbf{m V})\end{array}$ & $\begin{array}{l}\text { Surface } \\
\text { area }\left(\mathbf{m}^{2} / \mathbf{g}\right)\end{array}$ \\
\hline $\mathrm{ZnO}^{\mathrm{a}}$ & $47.1 \pm 5.1$ & $27.9 \pm 1.8$ & 90.8 & $14.8 \pm 11.3$ & 32.17 \\
$\mathrm{ZnO}^{\mathrm{b}}$ & $18.5 \pm 1.2$ & $6.8 \pm 0.5$ & 49.4 & $15.3 \pm 9.33$ & 17.03 \\
\hline
\end{tabular}

Abbreviations: DLS, dynamic light scattering; NPs, nanoparticles. and $\mathrm{ZnO}^{\mathrm{b}} \mathrm{NPs}$ (Figure 4B). Our results showed that the two $\mathrm{ZnO}$ NP types released zinc ions in the intracellular region. Zinc ions were detected rapidly after 1 hour, and $\mathrm{ZnO}^{\mathrm{b}} \mathrm{NPs}$ produced a significantly higher level of zinc ions in the intracellular region after 1 hour than $\mathrm{ZnO}^{\mathrm{a}} \mathrm{NPs}$. After the 3- and 5-hour treatments, significant zinc-fluorescence intensity was detected following exposure to both types of ZnO NPs. In this study, we also detected lysosomes, which are a type of organelle under acidic conditions. We found that regions with zinc ions merged with the lysosomes at all time points following exposure to both types of $\mathrm{ZnO}$ NPs.

\section{NAC inhibition effects on $\mathrm{ZnO}$ NP-induced cytotoxicity}

In this study, we detected inhibition effects of NAC, which is an ROS-scavenging agent. The results showed that NAC exhibited inhibition effects on $\mathrm{ZnO}^{a} \mathrm{NP}$ - and $\mathrm{ZnO}^{\mathrm{b}} \mathrm{NP}$-induced cell-viability loss after 24 hours of treatment (Figure 5A), particularly at concentrations $\geq 40 \mu \mathrm{g} / \mathrm{mL}$. Following $\mathrm{ZnO}^{\mathrm{a}}$ $\mathrm{NP}$ and $\mathrm{ZnO}^{\mathrm{b}} \mathrm{NP}$ treatments, cell viability decreased to nearly 


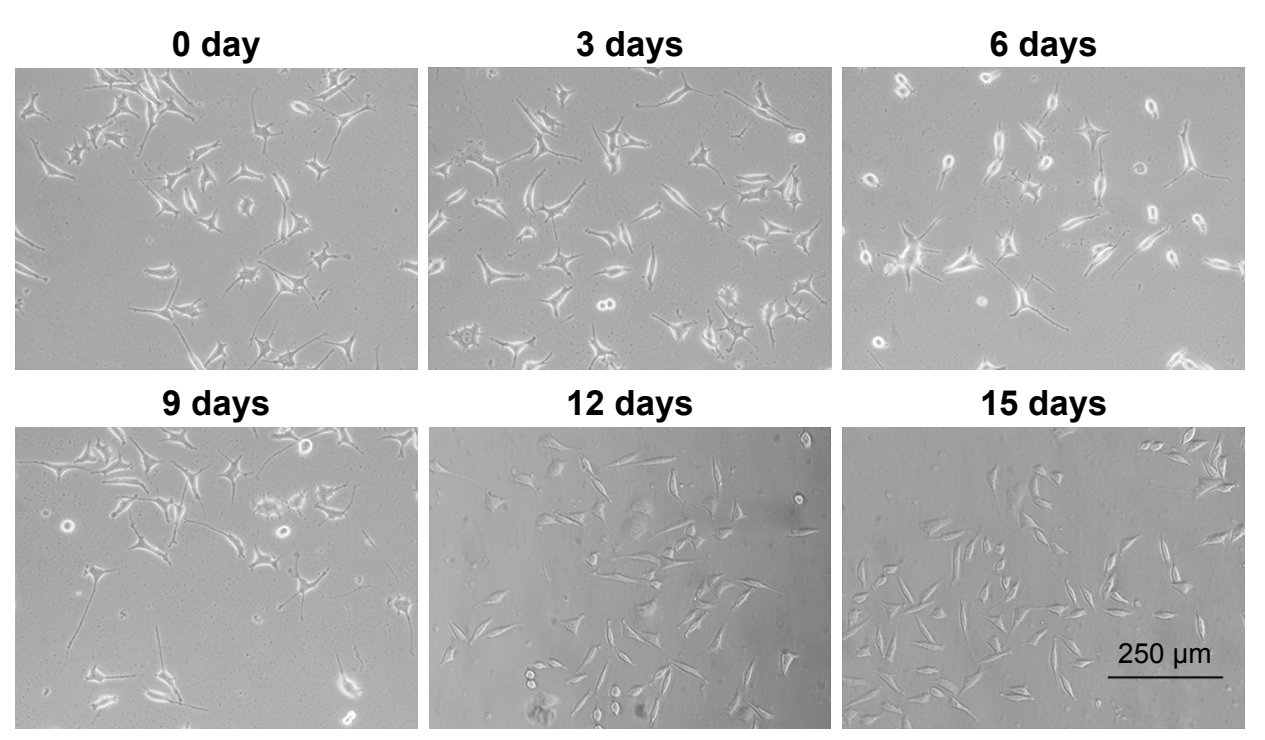

Figure 2 Trans-retinoic acid-induced SHSY5Y-cell differentiation. Scale bar $=250 \mu \mathrm{m}$. Magnification $\times 200$.

Notes: SHSY5Y cells were differentiated using trans-retinoic acid. Cell-morphology changes were observed at 0, 3, 6, 9, I2, and I5 days.
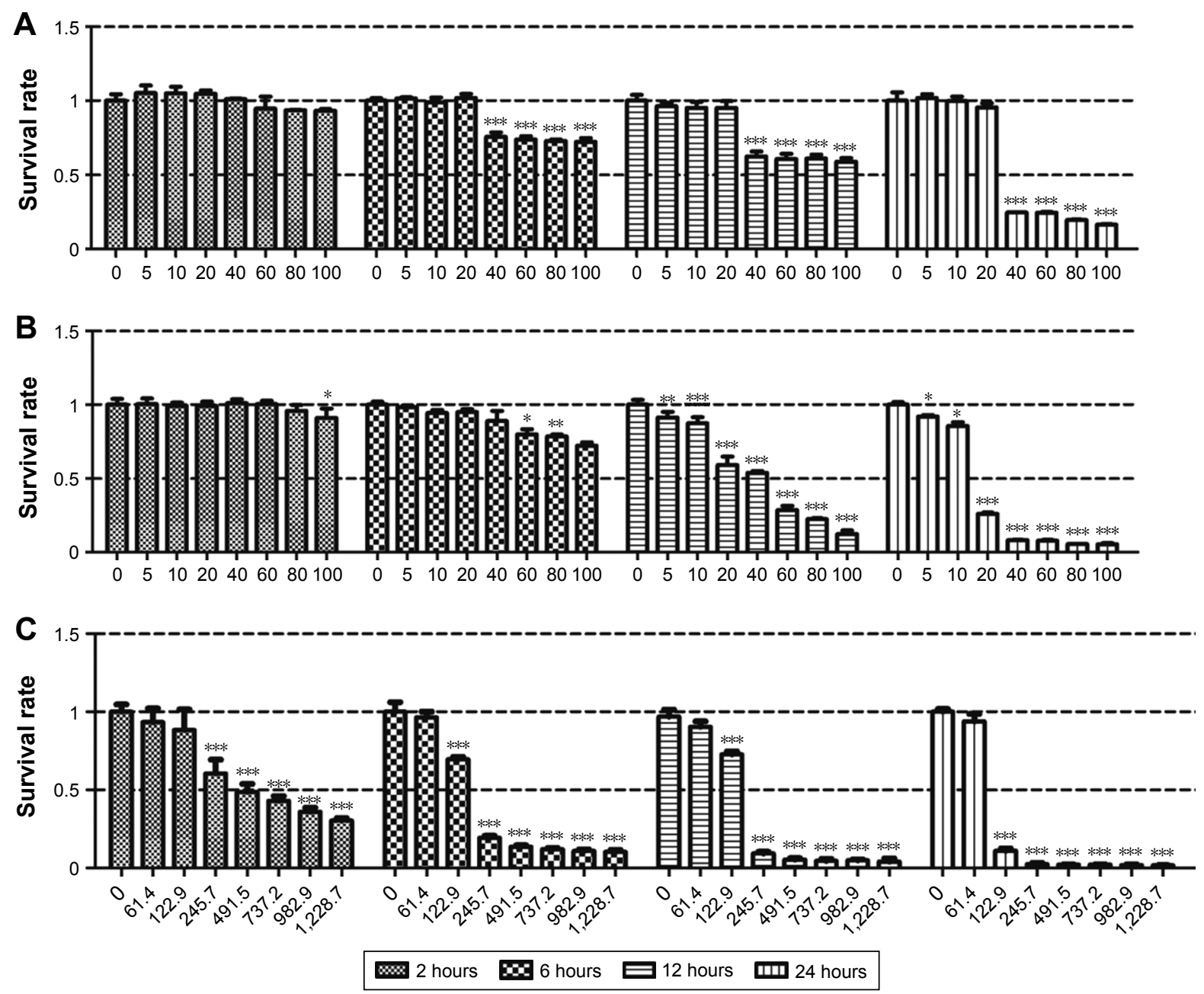

Figure 3 Two types of $\mathrm{ZnO} \mathrm{NP}$ - and $\mathrm{ZnCl}_{2}$-induced toxic effects in the SHSY5Y cells.

Notes: SHSY5Y cells were treated with ZnO NPs at concentrations of 0, 5, 10, 20, 40, 60, 80, and $100 \mu \mathrm{g} / \mathrm{mL}$ and $\mathrm{ZnCl}$ at concentrations of 0, 6I.4, I22.9, 245.7, 49I.5, 737.2, 982.9, and I,228.7 $\mu \mathrm{M}$ for 2, 6, 12, and 24 hours, and then cell viability was detected via CCK-8 assay. (A) ZnO $\mathrm{NP}^{\mathrm{a}}$-induced SHSY5Y cell-viability changes. (B) ZnO ${ }^{\mathrm{b}}$ NP-induced SHSY5Y cell-viability changes. (C) $\mathrm{ZnCl}_{2}$-induced SHSY5Y cell-viability changes. Results shown as means $\pm \mathrm{SEM}$. $* P<0.05$; $* * P<0.0 \mathrm{I}$; $* * * P<0.00 \mathrm{I}$. Abbreviation: NPs, nanoparticles. 


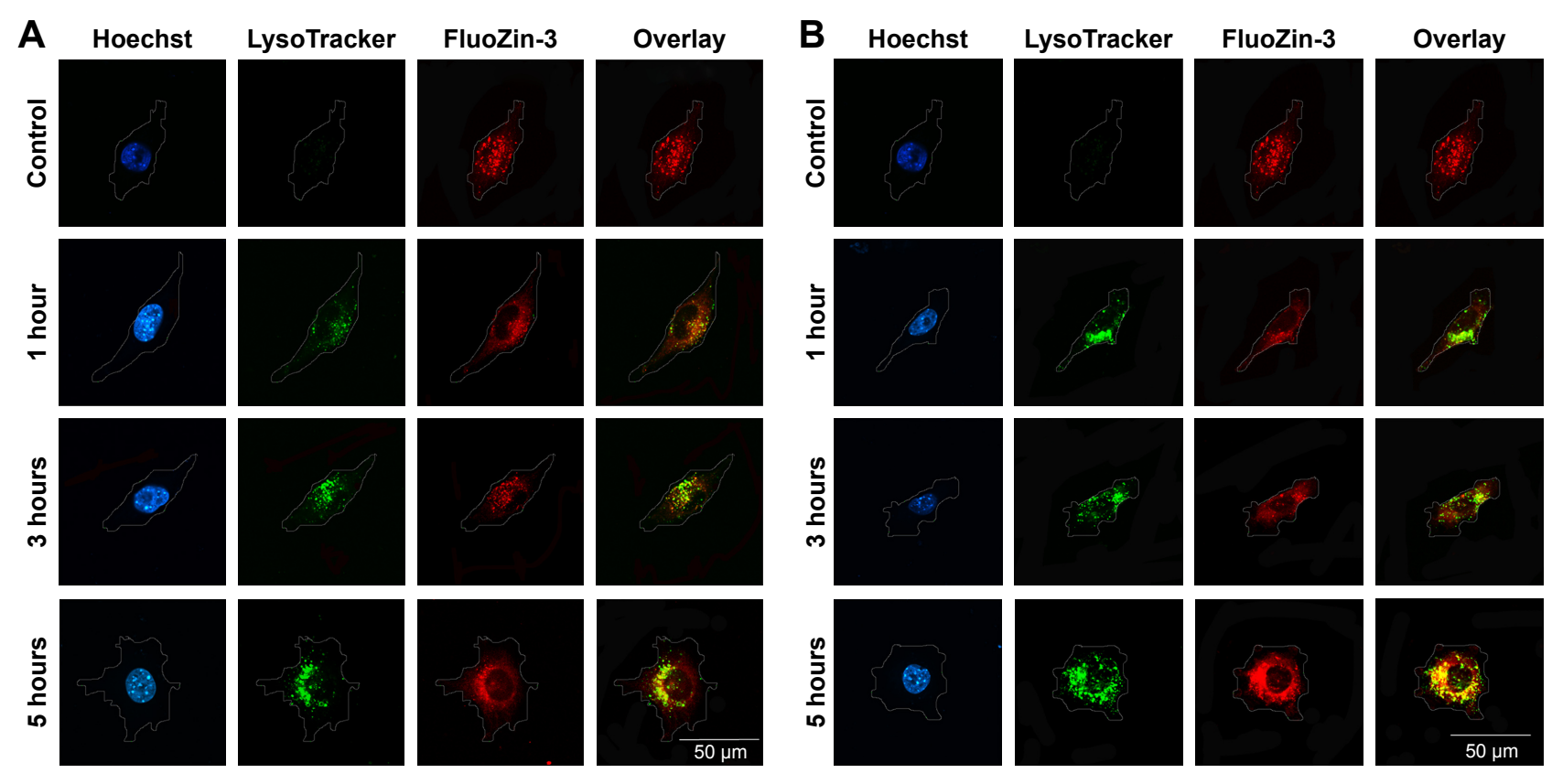

Figure 4 Confocal microscopy investigation of cellular distribution of lysosomes and zinc ions in SHSY5Y cells after the two ZnO NP treatments.

Notes: After SHSY5Y cells had been treated with $\mathrm{ZnO}^{\mathrm{a}} \mathrm{NPs}(\mathbf{A})$ and $\mathrm{ZnO} \mathrm{b}^{\mathrm{b}} \mathrm{NPs}(\mathbf{B})$ at a concentration of $50 \mu \mathrm{g} / \mathrm{mL}$ for I, 3, and 5 hours, the cells were loaded with FluoZin-3 (green), LysoTracker (red), and Hoechst 33342 (blue). We observed almost no zinc-ion fluorescence in the control group, but significant zinc ions (green) were observed within I hour after ZnO NP treatment and a slight increase in the zinc fluorescence (green) was observed in a time-dependent manner. Treatment with ZnO ${ }^{b}$ NPs exhibited higher fluorescence values than treatment with $\mathrm{ZnO}^{\mathrm{a}} \mathrm{NPs}$ at I hour. Moreover, significant overlaps (yellow) between the cellular zinc ions and lysosomes were observed at all time points. Scale bar $=50 \mu \mathrm{m}$. Magnification $\times 600$.

Abbreviation: NP, nanoparticle.

$25 \%$ and $8 \%$, respectively, at a concentration of $40 \mu \mathrm{g} / \mathrm{mL}$; however, after NAC treatment, viability remained at nearly $100 \%$ and $92 \%$, respectively. In addition, the inhibition effects of NAC weakened at concentrations $\geq 40 \mu \mathrm{g} / \mathrm{mL}$. Cell viability of $\mathrm{ZnO}^{\mathrm{a}} \mathrm{NP}$ - and $\mathrm{ZnO}^{\mathrm{b}} \mathrm{NP}$-treated cells in the presence of NAC was nearly $50 \%$ and $65 \%$, respectively, at a concentration of $100 \mu \mathrm{g} / \mathrm{mL}$. Moreover, we found that $\mathrm{NAC}$ also showed inhibition effects for $\mathrm{ZnCl}_{2}$ after $24 \mathrm{~h}$ of treatment, particularly at concentrations of $122.9 \mu \mathrm{M}$ and $245.7 \mu \mathrm{M}$ (Figure 5A). Cell viability decreased to $<10 \%$ after $\mathrm{ZnCl}_{2}$ treatment at concentrations $\geq 491.5 \mu \mathrm{M}$, even when combined with NAC.

\section{$\mathrm{ZnO}$ NP-induced ROS generation and oxidative stress-related gene changes}

In this study, we detected ROS generation after $\mathrm{ZnO}$ NP exposure to SHSY5Y cells (Figure 5B). Our results showed that the two types of $\mathrm{ZnO}$ NPs induced ROS generation in SHSY5Y cells, and this effect was most significant after 3 and 5 hours, respectively, at a concentration of $50 \mu \mathrm{g} / \mathrm{mL}$. $\mathrm{ZnO}^{\mathrm{b}}$ NPs showed higher ROS generation than $\mathrm{ZnO}^{\mathrm{a}} \mathrm{NPs}$. Moreover, significant ROS generation was observed after 1 hour following $\mathrm{ZnO}^{\mathrm{b}} \mathrm{NP}$ exposure, but not following $\mathrm{ZnO}^{\mathrm{a}}$ NPs exposure. Meanwhile, we also detected ROS generation after zinc-ion treatment at a concentration of $4 \mu \mathrm{g} / \mathrm{mL}$ (Figure 5B), which was similar to the zinc concentrations in the supernatants of these two $\mathrm{ZnO} N P$ types $(50 \mu \mathrm{g} / \mathrm{mL})$.

ROS generation was also detected after ZnO NP exposure at a concentration of $25 \mu \mathrm{g} / \mathrm{mL}$ (Figure 5C). Significant ROS generation was detected after 6,12 , and 24 hours of treatment with the two types of $\mathrm{ZnO}$ NPs, while significant ROS changes were not observed after 1 hour of treatment. $\mathrm{ZnO}^{\mathrm{b}}$ NPs showed higher ROS generation than $\mathrm{ZnO}^{\mathrm{a}}$ NPs after long-term treatment. The zinc ions did not show potent ROS generation at a concentration of $2 \mu \mathrm{g} / \mathrm{mL}$, which was similar to the zinc concentrations in the supernatants of the two types of $\mathrm{ZnO}$ NPs $(25 \mu \mathrm{g} / \mathrm{mL})$.

We then detected the changes in oxidative stress-related gene expression after 1-hour treatment with $\mathrm{ZnO}$ NPs and zinc ions (Figure 5D). Significant oxidative stressrelated gene changes were observed after treatment with the two $\mathrm{ZnO}$ NPs types in a concentration-dependent manner. A potent decrease in gene-expression levels was detected at $50 \mu \mathrm{g} / \mathrm{mL}$, including such genes as SOD2, CAT, and $G P X 1$. However, $\mathrm{ZnO}$ NPs induced a decrease in expression levels of the GPX1 and CAT genes at $25 \mu \mathrm{g} / \mathrm{mL}$. In addition, zinc ions, regardless of whether the concentration was $2 \mu \mathrm{g} / \mathrm{mL}$ or $4 \mu \mathrm{g} / \mathrm{mL}$, did not induce significant changes in gene levels. 

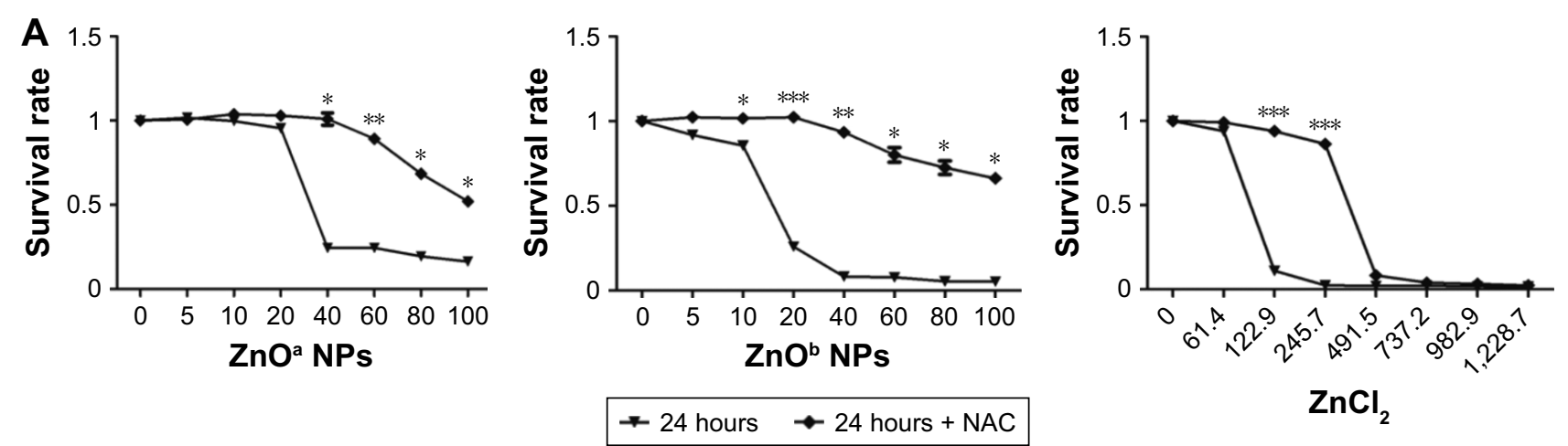

B

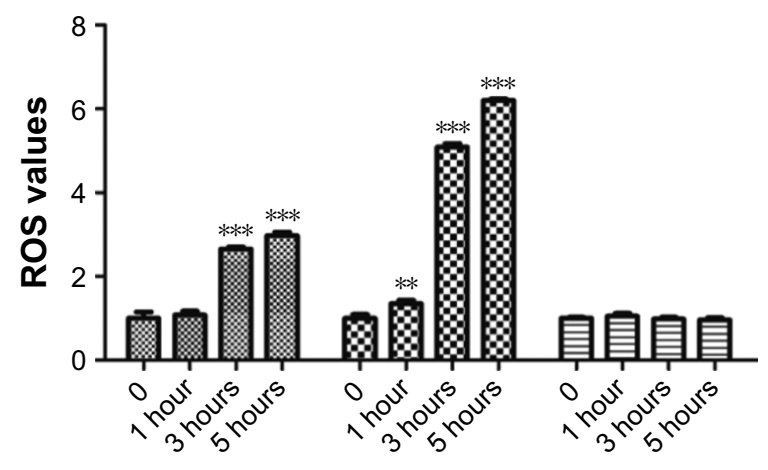

$\mathrm{ZnO}^{\mathrm{a}} \mathrm{NPs}$

D

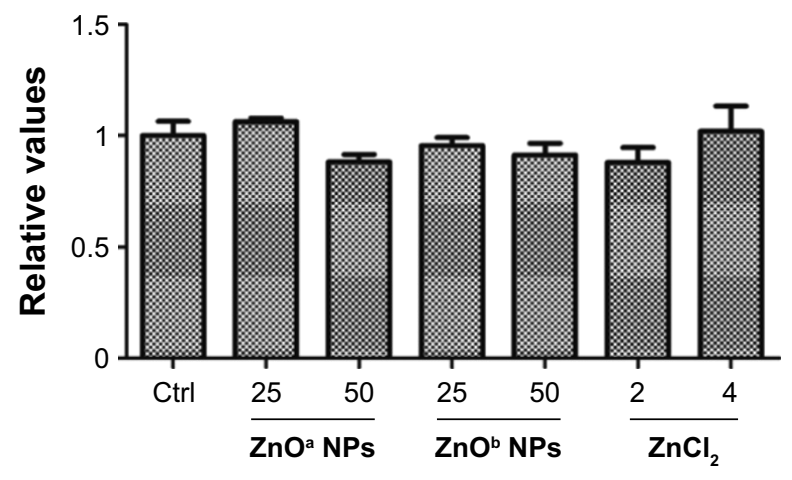

CAT

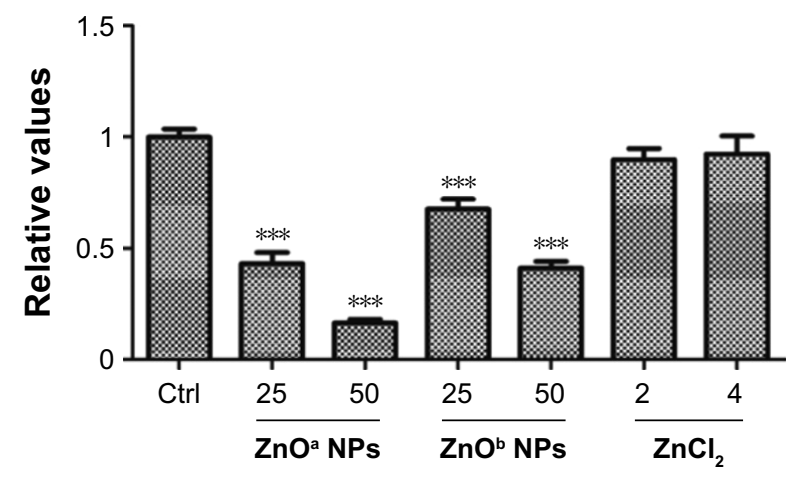

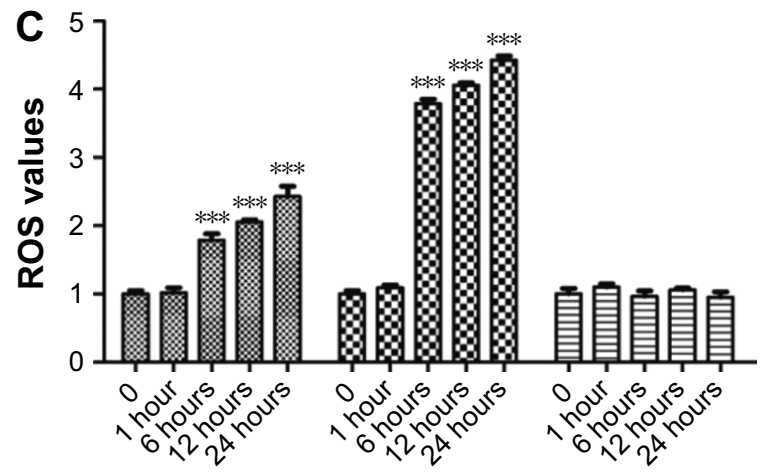

$\mathrm{ZnO} \mathrm{NPs}^{\mathrm{B}} \mathrm{Z \textrm {ZnCl } _ { 2 }}$

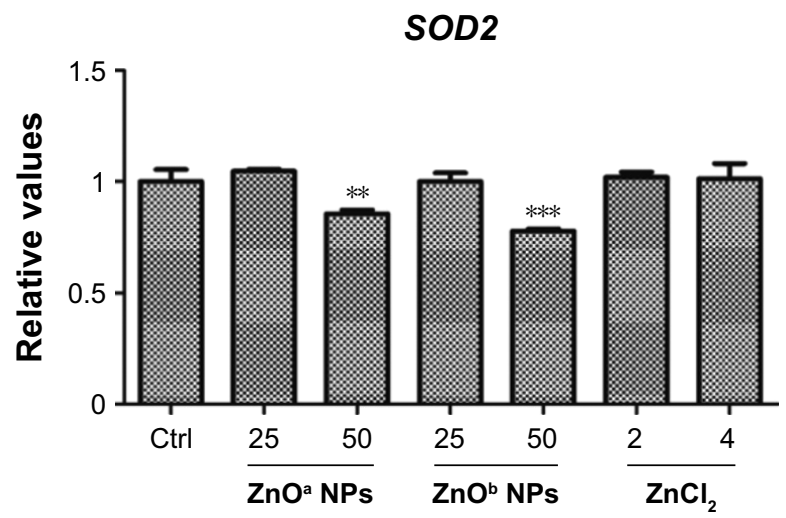

GPX1

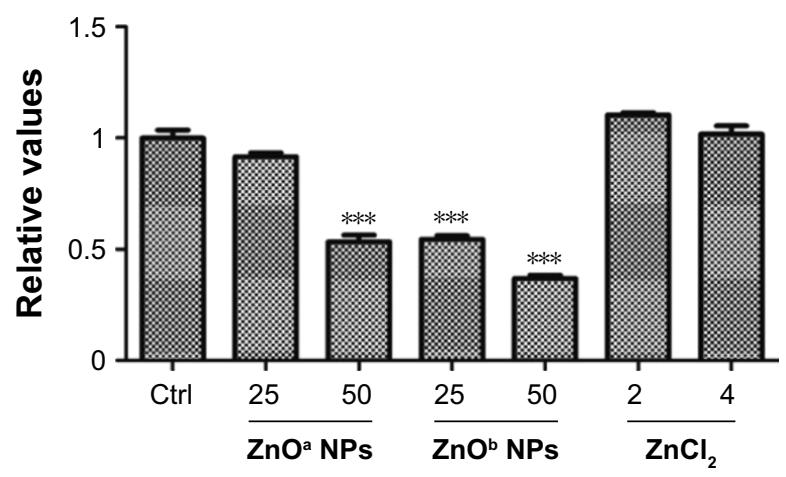

Figure 5 NAC inhibition effects on ZnO NP-induced cytotoxicity, ZnO NP-induced ROS generation, and oxidative stress-related gene changes.

Notes: (A) SHSY5Y cells were treated with $\mathrm{ZnO}^{a} \mathrm{NPs}, \mathrm{ZnO}^{b} \mathrm{NPs}$, and $\mathrm{ZnCl}_{2}$ at various concentrations for 24 hours, and $\mathrm{NAC}$ (I0 mM) was incubated simultaneously. Cell-viability data were obtained using CCK-8 assay. (B) ROS values in SHSY5Y cells after the ZnO NPs $(50 \mu \mathrm{g} / \mathrm{mL})$ and $\mathrm{ZnCl},(4 \mu \mathrm{g} / \mathrm{mL}) \mathrm{treatments}$ for I, 3 and $5 \mathrm{hours}$. (C) ROS values in SHSY5Y cells after the ZnO NPs $(25 \mu \mathrm{g} / \mathrm{mL})$ and $\mathrm{ZnCl}_{2}(2 \mu \mathrm{g} / \mathrm{mL})$ treatments for I, 6, 12 and 24 hours. (D) Oxidative stress-related gene changes in SHSY5Y cells after treatment with $\mathrm{ZnO} N P s$ and $\mathrm{ZnCl}_{2}$. Results shown as means $\pm \mathrm{SEM}$ of three independent experiments. $* P<0.05 ; * * P<0.01 ; * * * P<0.00 \mathrm{I}$.

Abbreviations: NAC, N-acetylcysteine; NP, nanoparticle; ROS, reactive oxygen species. 


\section{ZnO NP-induced apoptosis in SHSY5Y cell line}

Apoptosis levels in SHSY5Y cells were detected after $\mathrm{ZnO}$ NP exposure at various concentrations (Figure 6A). The results indicated that $\mathrm{ZnO}$ NPs induced apoptosis in a concentration-dependent manner. Following $\mathrm{ZnO}^{\mathrm{a}} \mathrm{NP}$ exposure for 5 hours, late-apoptosis levels were $2.3 \%, 3.1 \%$, and $3.1 \%$ at concentrations of 20,40 , and $60 \mu \mathrm{g} / \mathrm{mL}$, respectively. Late-apoptosis levels were $2.6 \%, 4.6 \%$, and $6.2 \%$ at the same concentrations of $\mathrm{ZnO}^{\mathrm{b}} \mathrm{NP}$ exposure, respectively. We found that the two $\mathrm{ZnO}$ NP types induced apoptosis in SHSY5Y cells, but $\mathrm{ZnO}^{\mathrm{b}} \mathrm{NPs}$ induced higher apoptosis levels than $\mathrm{ZnO}^{\mathrm{a}} \mathrm{NPs}$. Moreover, we detected apoptosis levels in the presence of zinc ions. Late-apoptosis levels were $0.5 \%, 1.2 \%$, and $1.1 \%$ for zinc ions at concentrations of $1.6,3.2$, and $4.8 \mu \mathrm{g} / \mathrm{mL}$, respectively, which were similar to zinc concentrations in the $\mathrm{ZnO}$ supernatants: 20,40 , and $60 \mu \mathrm{g} / \mathrm{mL}$. Moreover, we found that zinc ions at a concentration of $10 \mu \mathrm{g} / \mathrm{mL}$ induced significant apoptosis changes (late-apoptosis levels 33.8\%) and near-complete cell death $(99.9 \%)$ at a concentration of $20 \mu \mathrm{g} / \mathrm{mL}$.

Apoptosis-related genes were detected in this study after treatment with $\mathrm{ZnO}$ NPs and zinc ions for 1 hour (Figure 6B), and the expression of three apoptosis-related genes increased after $\mathrm{ZnO} \mathrm{NP}$ treatment. For $B A X$, a proapoptotic gene, a nearly sixfold increase was observed after treatment with $\mathrm{ZnO}$ NPs at a concentration of $50 \mu \mathrm{g} / \mathrm{mL}$, and compared to the control group, $\mathrm{ZnO}^{\mathrm{b}} \mathrm{NPs}(25 \mu \mathrm{g} / \mathrm{mL})$ induced a nearly fourfold change in $B A X$ expression; this value was higher than that of the $\mathrm{ZnO}^{\mathrm{a}} \mathrm{NPs}$ at a similar concentration (nearly double). We also detected a slight increase in the $B C L 2$ gene levels after treatment with the two $\mathrm{ZnO} \mathrm{NP}$ types in a concentration-dependent manner. Furthermore, the $B A X: B C L 2$ ratio increased significantly, indicating proapoptotic effects. $\mathrm{ZnO}^{\mathrm{a}} \mathrm{NPs}$ induced higher changes in gene-expression levels than $\mathrm{ZnO}^{\mathrm{b}} \mathrm{NPs}$ at a concentration of $50 \mu \mathrm{g} / \mathrm{mL}$. For $C Y T C$, a potent increase in gene-expression levels was observed for the two $\mathrm{ZnO}$ NP types at various concentrations. Zinc ions did not induce any gene changes at a concentration of $2 \mu \mathrm{g} / \mathrm{mL}$. However, a slight increase in gene-expression levels of $B A X$ and $B C L 2$ was observed after zinc-ion treatment at a concentration of $4 \mu \mathrm{g} / \mathrm{mL}$.

\section{ZnO NP-induced cytoskeleton changes in SHSY5Y cell line}

Morphology changes in SHSY5Y cells after exposure to $\mathrm{ZnO}^{\mathrm{a}} \mathrm{NPs}$ (Figure 7A) and $\mathrm{ZnO}^{\mathrm{b}} \mathrm{NPs}$ (Figure 7B) were observed. We used confocal microscopy to examine actin filaments and the microtubule system, and found that actin filaments were distributed in the cell membrane, while microtubules were located in the intracellular region between the cell nucleus and cell membrane. Moreover, there were no significant morphological changes in SHSY5Y cells after the two types of $\mathrm{ZnO}$ NP treatments. However, following $\mathrm{ZnO}^{\mathrm{b}} \mathrm{NP}$ treatment, actin agglomeration was observable after 3 hours, and particularly after 5 hours. Moreover, the microtubule system was observed to be encompassed by the cell nucleus, and the region between the cell membrane and cell nucleus was dull compared with that in the control group.

\section{Discussion}

$\mathrm{ZnO}$ nanomaterials are the most widely applied nanomaterials worldwide, and they are considered important components of cosmetics and electronic equipment. In this study, we explored the toxicological effects of $\mathrm{ZnO}$ NPs using two types of ZnO NPs with various sizes. Many studies have indicated that the physicochemical properties of nanomaterials, including size, ${ }^{15,25-27}$ shape,${ }^{28-30}$ surface area, ${ }^{31} \zeta$-potential, ${ }^{27,32}$ and composition, greatly affect their toxicological effects. ${ }^{23}$ The results of our study indicated that the $\mathrm{ZnO}^{\mathrm{a}} \mathrm{NPs}$ and $\mathrm{ZnO}^{\mathrm{b}} \mathrm{NPs}$ were rod-shaped with a low aspect ratio. Previous studies have shown that high-aspect-ratio particles, such as nanotubes, nanowires, and nanorods, might have more significant toxic effects. ${ }^{28-30}$ However, in this study, we believe that shape was not the main factor in toxicity discrepancy when comparing these two nanomaterials with low-aspect-ratio particles. Müller et $\mathrm{al}^{33}$ attributed the toxic effects of $\mathrm{ZnO}$ nanowires to released zinc ions, rather than to the high aspect ratio, implying that the rapid dissolution of $\mathrm{ZnO}$ may have reduced the effect of the NP shape. The average size of the $\mathrm{ZnO}^{\mathrm{a}} \mathrm{NPs}$ was $47.1 \pm 5.1 \mathrm{~nm}$, with width $27.9 \pm 1.8 \mathrm{~nm}$, and the average size of the $\mathrm{ZnO}^{\mathrm{b}} \mathrm{NPs}$ was $18.5 \pm 1.2 \mathrm{~nm}$, with width $6.8 \pm 0.5 \mathrm{~nm}$, which was smaller than that of the $\mathrm{ZnO}^{\mathrm{a}} \mathrm{NPs}$. As is well known, NPs can form agglomerates easily. ${ }^{34}$ Our results indicated that these two particle types showed agglomeration in the correct solvent, and the average sizes of the $\mathrm{ZnO}^{\mathrm{a}} \mathrm{NPs}$ and $\mathrm{ZnO}^{\mathrm{b}} \mathrm{NPs}$ in solvent were $90.8 \mathrm{~nm}$ and $49.4 \mathrm{~nm}$. $\mathrm{ZnO}^{\mathrm{a}} \mathrm{NPs}$ were larger in solvent than $\mathrm{ZnO}^{\mathrm{b}} \mathrm{NPs}$.

SHSY5Y cells are the most frequently used cell models and are derived from neuroblastoma. The differentiation of SHSY5Y cells is often induced by trans-retinoic acid to investigate their more neuron-like properties, such as their morphological changes and neuronal phenotypes. ${ }^{35}$ Undifferentiated SHSY5Y cells have also been used as cell models in studies in the field of neuroscience. ${ }^{36-38}$ However, a previous study has indicated that the undifferentiated SKNSH 

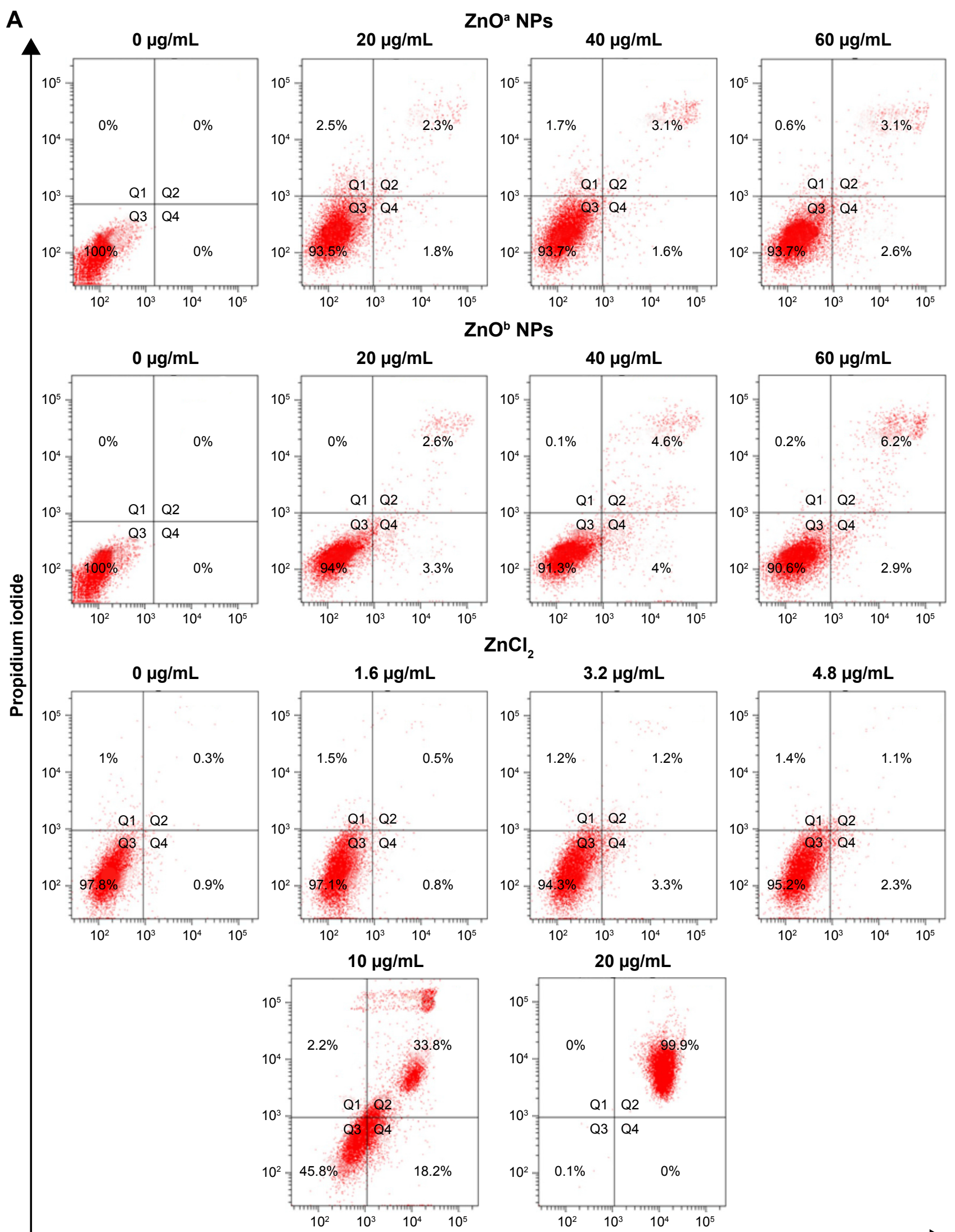

Annexin V-FITC

Figure 6 (Continued) 

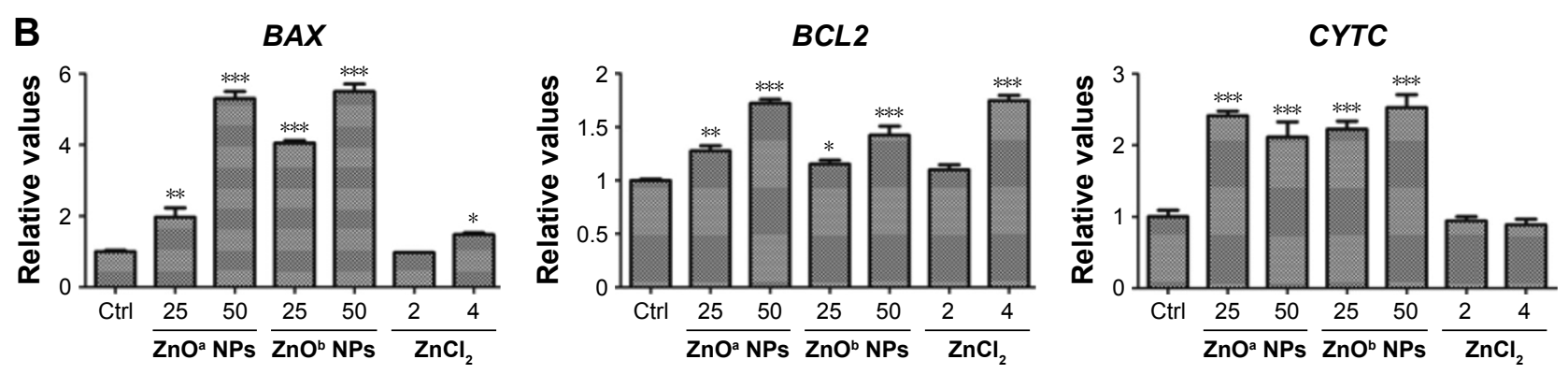

Figure 6 Two types of ZnO NP-induced apoptosis in SHSY5Y cells.

Notes: (A) After SHSY5Y cells had been treated with $\mathrm{ZnO}^{\mathrm{a}} \mathrm{NPs}, \mathrm{ZnO}^{\mathrm{b}} \mathrm{NPs}$, and $\mathrm{ZnCl}_{2}$ at various concentrations for 5 hours, cell-apoptosis levels were detected. (B) Apoptosis-related changes in gene expression in SHSY5Y cells after treatment with $\mathrm{ZnO} \mathrm{NPs}$ and $\mathrm{ZnCl}_{2}$. Results shown as means $\pm \mathrm{SEM}$ of three independent experiments. $* P<0.05 ; * * P<0.01$; $* * * P<0.00$ I.

Abbreviations: FITC, fluorescein isothiocyanate; NP, nanoparticle.

cell line, which was the original cell line of SHSY5Y cells, did not show significant neuronal properties compared with those of trans-retinoic acid-differentiated SKNSH cells. ${ }^{39}$ In our study, trans-retinoic acid-differentiated SHSY5Y cells exhibited significant morphological changes that were more consistent with those of the neurophenotypes. We found that neurites were extended and some cells became spindleshaped within 3 days. After 12 days of activation, almost all cells had a spindle shape.

Our results showed that $\mathrm{ZnO}$ NPs had significant toxic effects on the SHSY5Y cell line. Cell viability decreased rapidly when $\mathrm{ZnO} N P$ concentrations were $>40 \mu \mathrm{g} / \mathrm{mL}$, and there were no toxic effects after short-term exposure (2 hours). Cell viability decreased to $<50 \%$ after 24 hours' exposure at concentrations $\geq 40 \mu \mathrm{g} / \mathrm{mL}$. Many studies have shown that the cytotoxicity of nanomaterials depends on their size. ${ }^{15,25-27}$ Our study showed similar results. Compared to $\mathrm{ZnO}^{\mathrm{a}} \mathrm{NP}$ treatment, we found a larger number of significant toxic effects following $\mathrm{ZnO}^{\mathrm{b}} \mathrm{NP}$ treatment. $\mathrm{ZnO}^{\mathrm{b}} \mathrm{NPs}$ showed significant toxic effects, which decreased cell viability to almost $25 \%$ after 24 hours' exposure at a concentration of $20 \mu \mathrm{g} / \mathrm{mL}$; however, there were no toxic effects following $\mathrm{ZnO}^{\mathrm{a}} \mathrm{NP}$ treatment at the same concentration.

James et $\mathrm{al}^{40}$ found that $\mathrm{ZnO}$ NPs $(20 \mu \mathrm{g} / \mathrm{mL})$ induced a fourfold intracellular zinc-level increase, while $\mathrm{ZnCl}_{2}$ induced only a 1.3 -fold increase $(15 \mu \mathrm{g} / \mathrm{mL})$. These authors demonstrated that zinc ions were the main factor in $\mathrm{ZnO}$ NP-induced cytotoxicity. Another study showed that $\mathrm{ZnCl}_{2}$ induced toxic effects that were similar to those induced by $\mathrm{ZnO} \mathrm{NPs}$, and the oxidative stress and interactions of the zinc ions and their cellular targets were the main factors in $\mathrm{ZnO}$ NP-induced toxic response. ${ }^{25}$ Moreover, $\mathrm{ZnO}$ NP-induced toxic response decreased after treatment with EDTA, $\mathrm{CaCl}_{2}{ }^{41}$ or iron doping. ${ }^{42,43}$ These materials/methods can bind zinc ions or decrease $\mathrm{ZnO} \mathrm{NP}$ solubility. As our results indicated, zinc ions were more toxic than $\mathrm{ZnO}$ NPs
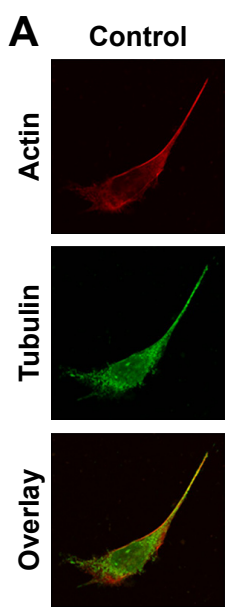
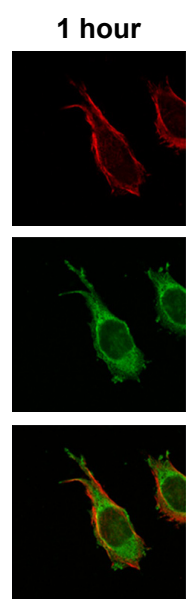
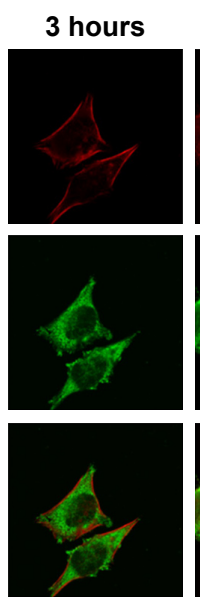
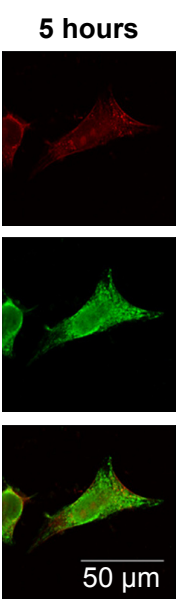
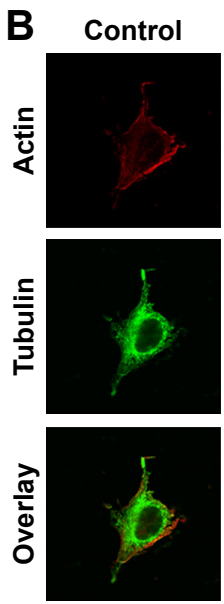
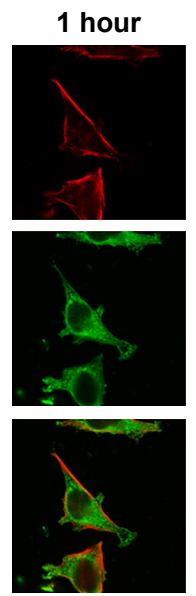
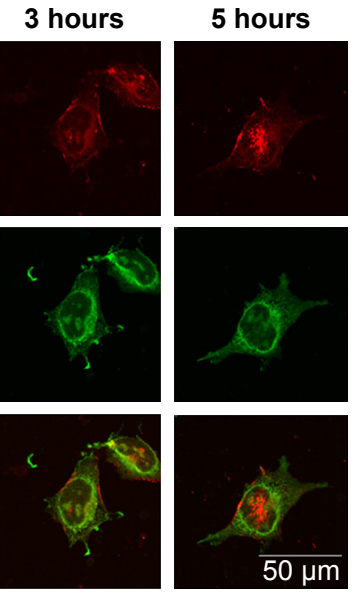

Figure 7 Two types of $\mathrm{ZnO}$ NP-induced cytoskeleton changes.

Notes: After SHSY5Y cells had been treated with ZnO $\mathrm{ZPs}^{\mathrm{a}}(\mathbf{A})$ and $\mathrm{ZnO}^{\mathrm{b}} \mathrm{NPs}(\mathbf{B})$ at concentrations of $50 \mu \mathrm{g} / \mathrm{mL}$ for I, 3, and 5 hours, cytoskeleton changes were assessed based on alterations in actin (red) and tubulin systems (green). Scale bar $=50 \mu \mathrm{m}$. Magnification $\times 600$.

Abbreviation: NP, nanoparticle. 
at the same zinc molar concentration. We detected zinc-ion concentrations in the supernatants after treatment with the two ZnO NP types, and our results showed that zinc-ion levels in the supernatants were low, much less than total zinc content in the ZnO NPs. Meanwhile, the zinc-ion level in the supernatants was approximately $4 \mu \mathrm{g} / \mathrm{mL}$ (approximately $61.4 \mu \mathrm{M}$ ) following treatment with the two $\mathrm{ZnO}$ NP types at a concentration of $50 \mu \mathrm{g} / \mathrm{mL}$, which did not induce any toxic effects in the SHSY5Y cells. We propose that the zinc ions in the supernatants were not the main factor in the $\mathrm{ZnO}$ NP-induced toxicological profile.

As a type of ion-shedding particle, $\mathrm{ZnO}$ NPs show high solubility in acidic environments. ${ }^{9}$ Wang et $\mathrm{al}^{44}$ found that vitamin $\mathrm{C}$ enhanced $\mathrm{ZnO} \mathrm{NP}$-induced toxicity due to its acidity, thereby accelerating $\mathrm{ZnO} \mathrm{NP}$ dissolution. Other studies have indicated that $\mathrm{ZnO}$ NPs can dissolve in lysosomes in an acidic environment. ${ }^{45,46} \mathrm{We}$ found $\mathrm{ZnO} \mathrm{NP}$ dissolution in the intracellular acid of vesicular organelles within 1 hour and that $\mathrm{ZnO}^{\mathrm{b}}$ showed a higher ion-shedding ability than $\mathrm{ZnO}^{\mathrm{a}}$. We believe that the zinc ion-shedding process can occur in the intracellular region and release zinc ions persistently, and this behavior is likely the main factor related to $\mathrm{ZnO}$ NP-induced toxic effects. We suggest that the zinc ions derived from the $\mathrm{ZnO}$ NPs played a major role in the related toxic responses, in which the ZnO NPs released zinc ions and induced cytotoxicity persistently. This persistent ion-shedding process may explain why the $\mathrm{ZnO}$ NPs induced a much weaker toxic response than $\mathrm{ZnCl}_{2}$ at the same molar concentration of zinc.

Some studies have indicated that $\mathrm{ZnO}$ NPs can alter the expression of oxidative- and apoptosis-related genes and proteins. ${ }^{14,47}$ As is well known, oxidative stress is considered a key factor in nanomaterial-induced toxic effects that trigger autophagy and apoptosis through distinct mechanisms. ${ }^{41,48-51}$ Oxidative stress is produced via ROS generation and a decrease in antioxidant factors, such as superoxide dismutase and glutathione, which have been reported to be the main factors in $\mathrm{ZnO}$ NP-induced toxic responses. ${ }^{52-54} \mathrm{Kim}$ et $\mathrm{al}^{55}$ indicated that $\mathrm{ROS}$, mainly $\mathrm{O}^{2-}$, were likely the main factors involved in $\mathrm{ZnO}$ NP-induced cell death, and the amount of ROS generated after $\mathrm{ZnO}$ NPs penetrate cells has been determined in macrophages. ${ }^{3}$ Our results supported this hypothesis. We found that NAC incubation significantly inhibited $\mathrm{ZnO}$ NP-induced decrease in cell viability. In addition, significant ROS generation and inhibition effects on the expression of antioxidant genes, particularly $C A T$ and $G P X 1$, were observed after treatment with the two types of ZnO NPs. Cells treated with $\mathrm{ZnO}^{\mathrm{b}} \mathrm{NPs}$ produced higher ROS levels than with $\mathrm{ZnO}^{\mathrm{a}} \mathrm{NPs}$, implying that the ROS generation depended on the particle size. Li et $\mathrm{al}^{31}$ found that smaller particles produced more ROS and exhibited higher toxic effects due to their larger surface area, allowing them to absorb more photons. Further, ZnO NP-induced oxidative stresses are likely due to their released zinc ions, which can activate ROS generation. ${ }^{56}$ According to our study, NAC significantly inhibited zinc ion-induced toxic effects, implying that ROS indeed play a crucial role in zinc ion-induced toxic effects. In addition, zinc ions released in the culture medium did not induce ROS generation or antioxidant-related gene changes. We think the persistent zinc ions release that occurred in the intracellular acidic vesicular organelles was probably the main cause of intracellular ROS generation.

We observed significant apoptosis after short-term $\mathrm{ZnO}$ $\mathrm{NP}$ exposure, and treatment with $\mathrm{ZnO}^{\mathrm{b}} \mathrm{NPs}$ resulted in higher apoptosis levels than treatment with $\mathrm{ZnO}^{\mathrm{a}} \mathrm{NPs}$. The zinc ions in the supernatants were probably not the main factor in apoptosis, while zinc ions at high concentrations significantly induced cell apoptosis, resulting in death. We think the persistent zinc ion release in the intracellular regions was probably the key factor in $\mathrm{ZnO}$-induced apoptosis. Mitochondria can sequester zinc ions into intracellular regions, leading to zinc-ion concentration elevation in the mitochondria and mitochondria dysfunction, and ultimately initiating apoptotic pathways, including the Bcl2-apoptosis pathway. ${ }^{57,58}$ Our results showed that apoptosis pathways were initiated after treatment with the two types $\mathrm{ZnO}$ NPs, particularly for the $\mathrm{Bcl} 2$ apoptotic family. Moreover, $\mathrm{ZnO} \mathrm{NP}$-induced ROS generation was regarded as one of the main causes of the initiation of apoptosis-related pathways. ${ }^{4}$

The SHSY5Y cell line is a traditional model in neuroscience. The cytoskeleton metabolism is a dynamic biological process that exhibits characteristics between polymerization and depolymerization; this process promotes and sustains cell morphology and functions. Many studies have indicated that nanomaterial exposure induces cytoskeleton disruption and cell-morphology changes. ${ }^{59-62}$ In our study, we did not observe significant cell-morphology changes in SHSY5Y cells, but some actin clustering was observed after ZnO NP treatments of $>3$ hours, indicating that dynamic actin polymerization was disrupted. Xu et $\mathrm{l}^{59}$ found that Ag NP exposure induced structural cell-cytoskeleton changes by altering the actin and tubulin systems. Chen et al ${ }^{63}$ observed cell shrinkage and actin rearrangement after Al NP treatment. Studies have attributed NP-induced cell-cytoskeleton changes to ROS generation. ${ }^{64,65}$ We suggest that these actin disturbances were likely attributable to $\mathrm{ZnO} \mathrm{NP}$-induced zinc-ion release and ROS generation. 


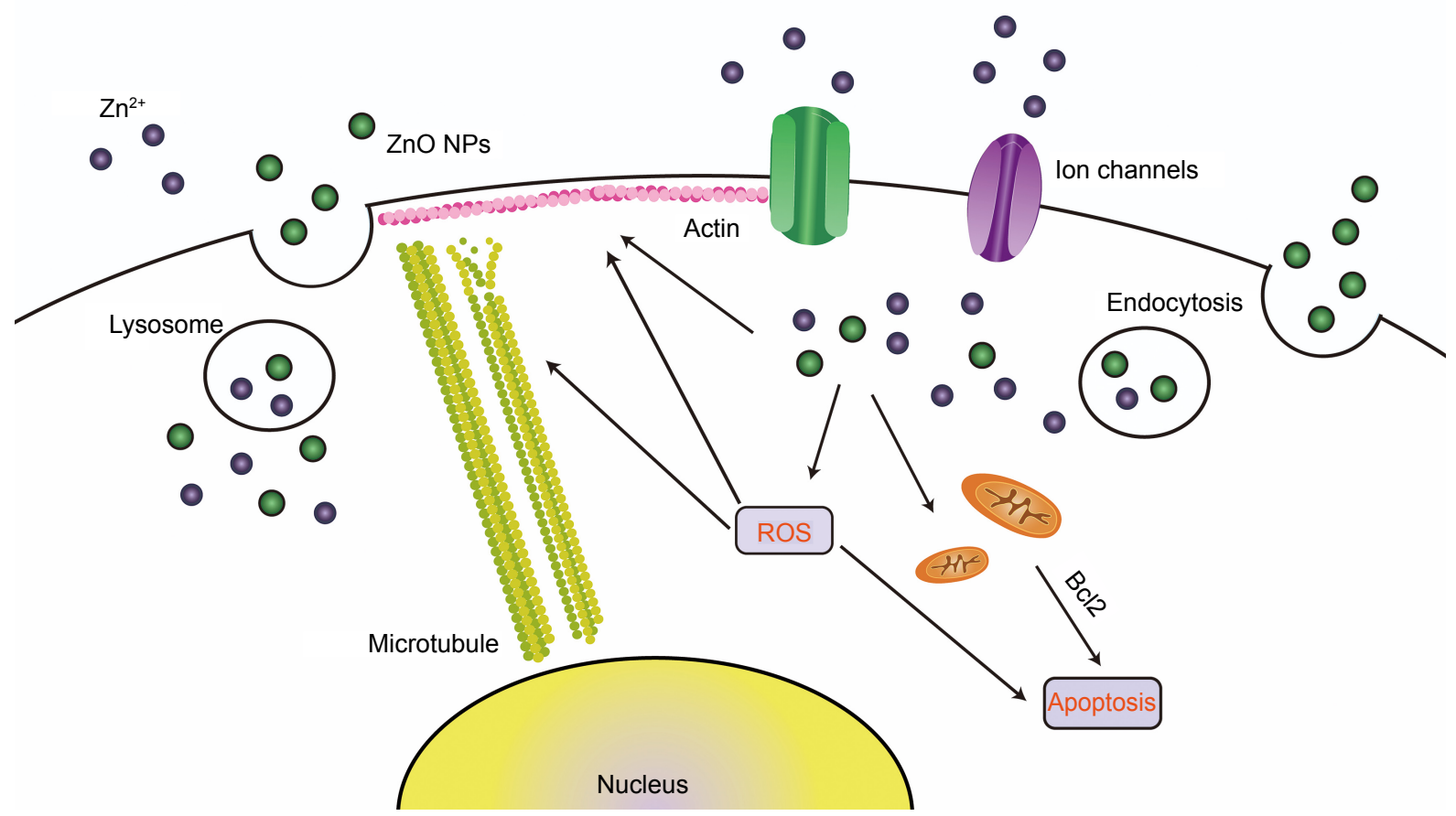

Figure $8 \mathrm{ZnO}$ NP-induced toxic effects in SHSY5Y cells.

Notes: $\mathrm{ZnO}$ NPs released zinc ions into the culture medium. Undissolved particles were endocytosed and dissolved into lysosomes due to the acidic environment. ZnO NPs and zinc ions induce ROS generation, resulting in apoptosis and cytoskeleton disruption.

Abbreviations: NP, nanoparticle; ROS, reactive oxygen species.

\section{Conclusion}

In conclusion, our data indicated that $\mathrm{ZnO}$ NPs induced significant cytotoxicity in a size-dependent manner, and detailed information is provided in Figure 8. ROS generation was observed after $\mathrm{ZnONP}$ treatment, and was a main factor in $\mathrm{ZnO}$ NP-induced toxic effects, which included decreasing cell viability and apoptosis. The $\mathrm{ZnO}$ NPs dissolved in acidic vesicular organelles and released zinc ion, which likely played a crucial role in the related toxic responses. The cytoskeleton changes were one of the main toxic effects of $\mathrm{ZnO}$ NPs. The findings of this study provide deep insights into the effects of NPs of different sizes, particularly soluble NPs, such as $\mathrm{ZnO}$, and provide more useful toxicological information on nanomaterials.

\section{Acknowledgments}

This work was supported by the National Key Research and Development Program of China (2016YFC1102601, 2016YFC1102603), the National Natural Science Foundation of China (51672122, 81600904), and the Natural Science Foundation of Guangdong Province (2015A030313299, 2016A030313673).

\section{Disclosure}

The authors report no conflicts of interest in this work.

\section{References}

1. Nowack B, Bucheli TD. Occurrence, behavior and effects of nanoparticles in the environment. Environ Pollut. 2007;150(1):5-22.

2. Giovanni M, Yue J, Zhang L, Xie J, Ong CN, Leong DT. Pro-inflammatory responses of RAW264.7 macrophages when treated with ultralow concentrations of silver, titanium dioxide, and zinc oxide nanoparticles. J Hazard Mater. 2015;297:146-152.

3. Song W, Zhang J, Guo J, et al. Role of the dissolved zinc ion and reactive oxygen species in cytotoxicity of $\mathrm{ZnO}$ nanoparticles. Toxicol Lett. 2010;199(3):389-397.

4. Setyawati MI, Tay CY, Leong DT. Effect of zinc oxide nanomaterialsinduced oxidative stress on the p53 pathway. Biomaterials. 2013;34(38): 10133-10142.

5. Liu J, Feng X, Wei L, Chen L, Song B, Shao L. The toxicology of ion-shedding zinc oxide nanoparticles. Crit Rev Toxicol. 2016;46(4): 348-384.

6. Cho WS, Kang BC, Lee JK, Jeong J, Che JH, Seok SH. Comparative absorption, distribution, and excretion of titanium dioxide and zinc oxide nanoparticles after repeated oral administration. Part Fibre Toxicol. 2013;10:9.

7. Palomäki J, Karisola P, Pylkkänen L, Savolainen K, Alenius H. Engineered nanomaterials cause cytotoxicity and activation on mouse antigen presenting cells. Toxicology. 2010;267(1-3):125-131.

8. Watson C, Ge J, Cohen J, Pyrgiotakis G, Engelward BP, Demokritou P. High-throughput screening platform for engineered nanoparticlemediated genotoxicity using CometChip technology. ACS Nano. 2014; 8(3):2118-2133.

9. Donaldson K, Schinwald A, Murphy F, et al. The biologically effective dose in inhalation nanotoxicology. Acc Chem Res. 2013;46(3) $723-732$.

10. Jiang C, Hsu-Kim H. Direct in situ measurement of dissolved zinc in the presence of zinc oxide nanoparticles using anodic stripping voltammetry. Environ Sci Process Impacts. 2014;16(11):2536-2544. 
11. Comfort KK, Braydich-Stolle LK, Maurer EI, Hussain SM. Less is more: long-term in vitro exposure to low levels of silver nanoparticles provides new insights for nanomaterial evaluation. ACS Nano. 2014;8(4): 3260-3271.

12. Jiang X, Miclaus T, Wang L, et al. Fast intracellular dissolution and persistent cellular uptake of silver nanoparticles in CHO-K1 cells: implication for cytotoxicity. Nanotoxicology. 2015;9(2):181-189.

13. Zhao J, Xu L, Zhang T, Ren G, Yang Z. Influences of nanoparticle zinc oxide on acutely isolated rat hippocampal CA3 pyramidal neurons. Neurotoxicology. 2009;30(2):220-230.

14. Valdiglesias V, Costa C, Kiliç G, et al. Neuronal cytotoxicity and genotoxicity induced by zinc oxide nanoparticles. Environ Int. 2013;55: 92-100.

15. Sahu D, Kannan GM, Vijayaraghavan R. Size-dependent effect of zinc oxide on toxicity and inflammatory potential of human monocytes. J Toxicol Environ Health A. 2014;77(4):177-191.

16. Amara S, Slama IB, Omri K, et al. Effects of nanoparticle zinc oxide on emotional behavior and trace element homeostasis in rat brain. Toxicol Industrial Health. 2013;31(12):1202-1209.

17. Shrivastava R, Raza S, Yadav A, Kushwaha P, Flora SJ. Effects of sub-acute exposure to $\mathrm{TiO}_{2}, \mathrm{ZnO}$ and $\mathrm{Al}_{2} \mathrm{O}_{3}$ nanoparticles on oxidative stress and histological changes in mouse liver and brain. Drug Chem Toxicol. 2014;37(3):336-347.

18. Yeh TK, Chen JK, Lin CH, et al. Kinetics and tissue distribution of neutron-activated zinc oxide nanoparticles and zinc nitrate in mice: effects of size and particulate nature. Nanotechnology. 2012;23(8):085102.

19. Kao YY, Cheng TJ, Yang DM, Wang CT, Chiung YM, Liu PS. Demonstration of an olfactory bulb-brain translocation pathway for $\mathrm{ZnO}$ nanoparticles in rodent cells in vitro and in vivo. J Mol Neurosci. 2012;48(2): 464-471.

20. Hsiao IL, Huang YJ. Effects of various physicochemical characteristics on the toxicities of $\mathrm{ZnO}$ and $\mathrm{TiO}$ nanoparticles toward human lung epithelial cells. Sci Total Environ. 2011;409(7):1219-1228.

21. Hanley C, Thurber A, Hanna C, Punnoose A, Zhang J, Wingett DG. The Influences of cell type and $\mathrm{ZnO}$ nanoparticle size on immune cell cytotoxicity and cytokine induction. Nanoscale Res Lett. 2009;4(12): 1409-1420.

22. Heng BC, Zhao X, Tan EC, et al. Evaluation of the cytotoxic and inflammatory potential of differentially shaped zinc oxide nanoparticles. Arch Toxicol. 2011;85(12):1517-1528.

23. Wang XZ, Yang Y, Li R, et al. Principal component and causal analysis of structural and acute in vitro toxicity data for nanoparticles. Nanotoxicology. 2014;8(5):465-476.

24. Deng X, Luan Q, Chen W, et al. Nanosized zinc oxide particles induce neural stem cell apoptosis. Nanotechnology. 2009;20(11):115101.

25. Feltis BN, Okeefe SJ, Harford AJ, Piva TJ, Turney TW, Wright PF. Independent cytotoxic and inflammatory responses to zinc oxide nanoparticles in human monocytes and macrophages. Nanotoxicology. 2012;6(7):757-765.

26. Prach M, Stone V, Proudfoot L. Zinc oxide nanoparticles and monocytes: impact of size, charge and solubility on activation status. Toxicol Appl Pharmacol. 2013;266(1):19-26.

27. Pan CH, Liu WT, Bien MY, et al. Effects of size and surface of zinc oxide and aluminum-doped zinc oxide nanoparticles on cell viability inferred by proteomic analyses. Int J Nanomedicine. 2014;9:3631-3643.

28. Bhattacharya D, Santra CR, Ghosh AN, Karmakar P. Differential toxicity of rod and spherical zinc oxide nanoparticles on human peripheral blood mononuclear cells. J Biomed Nanotechnol. 2014;10(4):707-716.

29. Ken D, Fiona AM, Rodger D, Craig AP. Asbestos, carbon nanotubes and the pleural mesothelium: a review of the hypothesis regarding the role of long fibre retention in the parietal pleura, inflammation and mesothelioma. Particle and Fibre Toxicology. 2010;7:5.

30. Schinwald A, Murphy FA, Jones A, Macnee W, Donaldson K. Graphenebased nanoplatelets: a new risk to the respiratory system as a consequence of their unusual aerodynamic properties. ACS Nano. 2012; 6(1):736-746.
31. Li Y, Zhang W, Niu J, Chen Y. Mechanism of photogenerated reactive oxygen species and correlation with the antibacterial properties of engineered metal-oxide nanoparticles. ACS Nano. 2012;6(6):5164-5173.

32. Zhang J, Dong G, Thurber A, et al. Tuning the properties of $\mathrm{ZnO}$, hematite, and Ag nanoparticles by adjusting the surface charge. Adv Mater. 2012;24(9):1232-1237.

33. Müller KH, Kulkarni J, Motskin M, et al. pH-dependent toxicity of high aspect ratio $\mathrm{ZnO}$ nanowires in macrophages due to intracellular dissolution. ACS Nano. 2010;4(11):6767-6779.

34. Tso CP, Zhung CM, Shih YH, Tseng YM, Wu SC, Doong RA. Stability of metal oxide nanoparticles in aqueous solutions. Water Sci Technol. 2010;61(1):127-133.

35. Pahlman S, Ruusala AI, Abrahamsson L, Mattsson ME, Esscher T. Retinoic acid-induced differentiation of cultured human neuroblastoma cells: a comparison with phorbolester-induced differentiation. Cell Differ. 1984;14(2):135-144.

36. Levites Y, Youdim MB, Maor G, Mandel S. Attenuation of 6-hydroxydopamine (6-OHDA)-induced nuclear factor- $\kappa \mathrm{B}(\mathrm{NF}-\kappa \mathrm{B})$ activation and cell death by tea extracts in neuronal cultures. Biochem Pharmacol. 2002;63(1):21-29.

37. Lee JH, Shin SY, Kim S, Choo J, Lee YH. Suppression of PTEN expression during aggregation with retinoic acid in P19 mouse embryonal carcinoma cells. Biochem Biophys Res Commun. 2006;347(3):715-722.

38. Xue S, Jia L, Jia J. Hypoxia and reoxygenation increased BACE1 mRNA and protein levels in human neuroblastoma SH-SY5Y cells. Neurosci Lett. 2006;405(3):231-235.

39. Lombet A, Zujovic V, Kandouz M, et al. Resistance to induced apoptosis in the human neuroblastoma cell line SK-N-SH in relation to neuronal differentiation: role of Bcl-2 protein family. Eur J Biochem. 2001;268(5): 1352-1362.

40. James SA, Feltis BN, de Jonge MD, et al. Quantification of ZnO nanoparticle uptake, distribution, and dissolution within individual human macrophages. ACS Nano. 2013;7(12):10621-10635.

41. Johnson BM, Fraietta JA, Gracias DT, et al. Acute exposure to ZnO nanoparticles induces autophagic immune cell death. Nanotoxicology. 2015;9(6):737-748.

42. Xia T, Zhao Y, Sager T, et al. Decreased dissolution of $\mathrm{ZnO}$ by iron doping yields nanoparticles with reduced toxicity in the rodent lung and zebrafish embryos. ACS Nano. 2011;5(2):1223-1235.

43. George S, Pokhrel S, Xia T, et al. Use of a rapid cytotoxicity screening approach to engineer a safer zinc oxide nanoparticle through iron doping. ACS Nano. 2010;4(1):15-29.

44. Wang Y, Yuan L, Yao C, et al. A combined toxicity study of zinc oxide nanoparticles and vitamin C in food additives. Nanoscale. 2014;6(24): 15333-15342.

45. Xia T, Kovochich M, Liong M, et al. Comparison of the mechanism of toxicity of zinc oxide and cerium oxide nanoparticles based on dissolution and oxidative stress properties. ACS Nano. 2008;2(10):2121-2134.

46. Müller KH, Kulkarni J, Motskin M, et al. pH-dependent toxicity of high aspect ratio $\mathrm{ZnO}$ nanowires in macrophages due to intracellular dissolution. ACS Nano. 2010;4(11):6767-6779.

47. Huang CC, Aronstam RS, Chen DR, Huang YW. Oxidative stress, calcium homeostasis, and altered gene expression in human lung epithelial cells exposed to $\mathrm{ZnO}$ nanoparticles. Toxicol In Vitro. 2010; 24(1):45-55.

48. Karna P, Zughaier S, Pannu V, Simmons R, Narayan S, Aneja R. Induction of reactive oxygen species-mediated autophagy by a novel microtubulemodulating agent. J Biol Chem. 2010;285(24):18737-18748.

49. Rikiishi H. Novel insights into the interplay between apoptosis and autophagy. Int J Cell Biol. 2012;2012:317645.

50. Yu KN, Yoon TJ, Minai-Tehrani A, et al. Zinc oxide nanoparticle induced autophagic cell death and mitochondrial damage via reactive oxygen species generation. Toxicol In Vitro. 2013;27(4):1187-1195.

51. Roy R, Singh SK, Chauhan LK, Das M, Tripathi A, Dwivedi PD. Zinc oxide nanoparticles induce apoptosis by enhancement of autophagy via PI3K/Akt/mTOR inhibition. Toxicol Lett. 2014;227(1):29-40. 
52. Saptarshi SR, Feltis BN, Wright PF, Lopata AL. Investigating the immunomodulatory nature of zinc oxide nanoparticles at sub-cytotoxic levels in vitro and after intranasal instillation in vivo. J Nanobiotechnology. 2015;13:6

53. De Angelis I, Barone F, Zijno A, et al. Comparative study of $\mathrm{ZnO}$ and $\mathrm{TiO}_{2}$ nanoparticles: physicochemical characterisation and toxicological effects on human colon carcinoma cells. Nanotoxicology. 2013;7(8): 1361-1372.

54. Guan R, Kang T, Lu F, Zhang Z, Shen H, Liu M. Cytotoxicity, oxidative stress, and genotoxicity in human hepatocyte and embryonic kidney cells exposed to ZnO nanoparticles. Nanoscale Res Lett. 2012; 7(1):602.

55. Kim AR, Ahmed FR, Jung GY, Cho SW, Kim DI, Um SH. Hepatocyte cytotoxicity evaluation with zinc oxide nanoparticles. J Biomed Nanotechnol. 2013;9(5):926-929.

56. Fukui H, Horie M, Endoh S, et al. Association of zinc ion release and oxidative stress induced by intratracheal instillation of $\mathrm{ZnO}$ nanoparticles to rat lung. Chem Biol Interact. 2012;198(1-3):29-37.

57. Kao YY, Chen YC, Cheng TJ, Chiung YM, Liu PS. Zinc oxide nanoparticles interfere with zinc ion homeostasis to cause cytotoxicity. Toxicol Sci. 2012;125(2):462-472.

58. Guo D, Bi H, Wu Q, Wang D, Cui Y. Zinc oxide nanoparticles induce rat retinal ganglion cell damage through Bcl-2, caspase-9 and caspase-12 pathways. J Nanosci Nanotechnol. 2013;13(6):3769-3777.
59. Xu F, Piett C, Farkas S, Qazzaz M, Syed NI. Silver nanoparticles (AgNPs) cause degeneration of cytoskeleton and disrupt synaptic machinery of cultured cortical neurons. Mol Brain. 2013;6:29.

60. Soenen SJ, Manshian B, Montenegro JM, et al. Cytotoxic effects of gold nanoparticles: a multiparametric study. ACS Nano. 2012;6(7): 5767-5783.

61. Wu J, Wang C, Sun J, Xue Y. Neurotoxicity of silica nanoparticles: brain localization and dopaminergic neurons damage pathways. ACS Nano. 2011;5(6):4476-4489.

62. Yang X, He C, Li J, et al. Uptake of silica nanoparticles: neurotoxicity and Alzheimer-like pathology in human SK-N-SH and mouse neuro2a neuroblastoma cells. Toxicol Lett. 2014;229(1):240-249.

63. Chen L, Yokel RA, Hennig B, Toborek M. Manufactured aluminum oxide nanoparticles decrease expression of tight junction proteins in brain vasculature. J Neuroimmune Pharmacol. 2008;3(4):286-295.

64. Apopa PL, Qian Y, Shao R, et al. Iron oxide nanoparticles induce human microvascular endothelial cell permeability through reactive oxygen species production and microtubule remodeling. Part Fibre Toxicol. 2009;6:1.

65. Lee CF, Liu CY, Hsieh RH, Wei YH. Oxidative stress-induced depolymerization of microtubules and alteration of mitochondrial mass in human cells. Ann N Y Acad Sci. 2005;1042:246-254.
International Journal of Nanomedicine

\section{Publish your work in this journal}

The International Journal of Nanomedicine is an international, peerreviewed journal focusing on the application of nanotechnology in diagnostics, therapeutics, and drug delivery systems throughout the biomedical field. This journal is indexed on PubMed Central, MedLine, CAS, SciSearch $®$, Current Contents $\AA /$ Clinical Medicine,

\section{Dovepress}

Journal Citation Reports/Science Edition, EMBase, Scopus and the Elsevier Bibliographic databases. The manuscript management system is completely online and includes a very quick and fair peer-review system, which is all easy to use. Visit http://www.dovepress.com/ testimonials.php to read real quotes from published authors. 